\title{
Biological activity of mistletoe: in vitro and in vivo studies and mechanisms of action
}

\author{
Anna Szurpnicka ${ }^{1}\left[\right.$ • Anna Kowalczuk ${ }^{2}$. \\ Arkadiusz Szterk $^{3}$
}

Received: 17 December 2019 / Accepted: 29 June 2020 / Published online: 3 July 2020

(C) The Author(s) 2020

\begin{abstract}
Mistletoe has been used as treatment of many diseases in traditional and folk medicine. To date, anticancer, immunomodulatory, cardiac, antidiabetic, hepatoprotective, neuropharmacological, antibacterial and antifungal properties of mistletoe extracts have been studied the most. In this review, we summarized in vitro and in vivo studies on the pharmacological activity of Viscum species. Furthermore, we proposed the possible mechanisms of action of this herb, which might include many signalling pathways. Mistletoe could regulate either similar or different targets in various pathways that act on membrane receptors, enzymes, ion channels, transporter proteins and transcriptional targets. Still, pharmacological activities of mistletoe have been investigated mainly for crude extracts. It is a new field for scientists to determined which chemical compounds are responsible for the individual biological activities of mistletoe and how these activities are achieved. As a result, mistletoe might become a source of new complementary therapies supporting the treatment of many diseases.
\end{abstract}

Keywords Mistletoe $\cdot$ Viscum Extracts $\cdot$ Bioactivities · Mechanisms $\cdot$ Pharmacognosy

Anna Szurpnicka

annaszurpnicka@gmail.com

1 Department of Natural Medicinal Products and Dietary Supplements, National Medicines Institute, Chełmska 30/34, 00-725 Warsaw, Poland

2 National Medicines Institute, Chełmska 30/34, 00-725 Warsaw, Poland

3 Department of Spectrometric Methods, National Medicines Institute, Chełmska 30/34, 00-725 Warsaw, Poland

\section{Introduction}

Mistletoe (Viscum L.) belongs to the family of Viscaceae. In Europe, Asia, Africa and Australia, about 100 species of mistletoe can be distinguished, of which the most known are in Santalaceae: Viscum album L. (European mistletoe), Santalaceae: Viscum album subsp. Coloratum Kom. (Viscum coloratum (Kom.) Nakai, Korean mistletoe), Santalaceae: Viscum articulatum Burm. f., Santalaceae: Viscum shimperi Engl., Santalaceae: Viscum capense L.f. and Santalaceae: Viscum cruciatum Sieber ex Boiss. Mistletoe is a semi-parasitic evergreen shrub, which means it depends on having water and some nutrients supplied from another plant (host tree) while it produces carbohydrates in a process of photosynthesis. Viscum species inhabit many types of wooded habitats and parasitize both deciduous and coniferous trees (Bussing 2000). For clinical applications, the most popular species are mistletoe parasitizing fir, maple, almond, birch, hawthorn, ash, apple, pine, poplar, oak, willow, lime and elm (Kienle et al. 2011). Viscum species have been used in the traditional medicine of Europe for centuries. Hippocrates used mistletoe to treat diseases of the spleen and complaints associated with menstruation, while Pliny the Elder used it to treat epilepsy, infertility and ulcers. In the Middle Ages, Paracelsus recommended mistletoe as a treatment for epilepsy. Hildegard von Bingen described mistletoe as a treatment for diseases of the spleen and liver. Mistletoe was also applied for deworming children, to treat labour pains, gout, affections of the lungs and liver, leprosy, mumps, fractures and hepatitis. During the eighteenth century, mistletoe was applied for "weakness of the heart" and oedema (Bussing 2000). By the end of the nineteenth century, mistletoe was rejected by scientists as a folklore remedy. The scientific interest on mistletoe was awakened in the twentieth century, as Gaultier investigated the effect of oral or subcutaneous 
applications of fresh Viscum album L. extracts on blood pressure in humans and animals (Bussing 2000; Committee on Herbal Medicinal Products 2012). In 1920, Viscum album L. was introduced as a cancer treatment by Rudolf Steiner who recommended a drug extract produced in a complicated manufacturing process combining sap from mistletoe harvested in the winter and summer (Bussing 2000). Mistletoe was also commonly used in other parts of the world. In Japan, mistletoe was used to treat hypertension, spasms of the heart, rheumatic pain, threatened abortion and locally to treat frostbite. In India, a tea prepared from mistletoe leaves was used to treat diabetes, while a preparation of Viscum articulatum Burm. f. was given in fevers with aching limbs. In Africa, Viscum species were a remedy to treat diarrhoea and an enema for stomach troubles in children. In Israel, Viscum cruciatum Sieber ex Boiss. was commonly used to treat constipation in young children and adults. Mistletoe was also used against general pain, backache and arthritis. In the traditional medicine of Egypt, the plant was used for the treatment of epilepsy, arteriosclerosis, and diseases of cardiac arteries, and as a hypotensive (Bussing 2000; Lev et al. 2011; Committee on Herbal Medicinal Products 2012). Such varied pharmaceutical applications result from the rich chemical composition of Viscum species, which largely depend on the host species. The main active compounds are lectins, viscotoxins, flavonoids, phenolic acids, sterols, lignans, terpenoids, phenylpropanoids, alkaloids and fatty acids (Szurpnicka et al. 2019). In this review, we would like to summarize the scientific data on the pharmacological activity of Viscum species and analyse the probable mechanisms of actions of mistletoe.

\section{Anticancer and immunomodulatory activity}

In German-speaking countries, mistletoe has been used as complementary anticancer therapy for more than 100 years. Viscum album L. preparations can be divided into phytotherapeutic extracts standardized on a certain lectin level (brand names such as Cefalektin, Eurixor, Lektinol) and anthroposophical/homeopathically produced extracts (brand names such as AbnobaViscum, Helixor, Iscador, Iscucin, Isorel) (Freuding et al. 2019). The main anticancer compounds isolated from Viscum species are lectins (Thies et al. 2005; Eggenschwiler et al. 2007) and viscotoxins (Schaller et al. 1996). Later studies have shown that other compounds, such as phenolic compounds (Melo et al. 2018), triterpene acids (Delebinski et al. 2015) and non-polar compounds (Ćebović et al. 2008), have also shown antitumor properties. Furthermore, it was reported that complete mistletoe extract is more potent at inhibiting tumour cells than isolated compounds (Felenda et al. 2019), and there is synergistic action between different groups of mistletoe compounds (Twardziok et al.
2016; Kleinsimon et al. 2017). Mistletoe shows bi-directional activity in the treatment of cancer. Firstly, it affects the quality of life of cancer patients by the improvement of fatigue, sleep, exhaustion, nausea, vomiting, appetite, depression, anxiety, pain and side effects of traditional treatment (Kienle and Kiene 2010; Brandenberger et al. 2012; Kim et al. 2012). Secondly, it shows antitumor activity by cytotoxicity, induction of apoptosis (Ćebović et al. 2008; Park et al. 2012; Han et al. 2015; Mishra et al. 2018) and inhibition of angiogenesis (Park et al. 2001; Elluru et al. 2009). The mechanism of action is shown in Fig. 1. In vitro studies on anticancer activity of mistletoe have confirmed that it modulates many different pathways, playing key roles in tumour proliferation, including MAPK (mitogen-activated protein kinase) (Park et al. 2012) and PI3K/AKT (phosphatidylinositol 3-kinase/protein kinase B) (Fan et al. 2019). Furthermore, mistletoe can cause cell cycle arrest (Dela Cruz et al. 2015; Kim et al. 2017; Melo et al. 2018), loss of mitochondrial membrane permeability (MMP) (Mishra et al. 2018) and can activate caspases and regulate pro- and anti-apoptotic proteins (Fan et al. 2019) (Table 1). The anticancer activity of Viscum species is linked with their immunomodulatory activity (Oei et al. 2019), such as the increase of maturation and activation of dendritic cells (Elluru et al. 2008; Kim et al. 2014a; Steinborn et al. 2017), abrogation of tumour-induced immunosuppression of dendritic cells (Steinborn et al. 2017), increase of leukocytes, eosinophils, granulocytes (Huber et al. 2005, 2011) and lymphocytes (Semiglasov et al. 2004), increase of cytokines secretion (Hajto et al. 1990; Kovacs 2000; Elluru et al. 2008), increase of activity of natural killer cells (Hajto 1986; Tabiasco et al. 2002; Braedel-Ruoff 2010; Kim et al. 2018), increase of the activities of natural killer cells during surgery (Schink et al. 2007) and enhancement of cellular and humoral immune response (Yoon et al. 2001; Gardin 2009). Clinical studies were done on patients suffering from cancer diseases such as bladder cancer, breast cancer, colorectal cancer, glioma, lung cancer, melanoma and the results of these studies have been published in many articles. Those who are interested in the topic are invited to read review articles focusing on the anticancer properties of mistletoe (Ernst et al. 2003; Bar-Sela 2011; Bar-Sela et al. 2013; Steele et al. 2015; Kienle et al. 2016; Schläppi et al. 2017; Freuding et al. 2019). Additionally, it is worth paying attention to studies regarding synergistic interactions of mistletoe preparations with other cancer treatments such as chemotherapy and radiotherapy (Siegle et al. 2001; Hong et al. 2014; Kleinsimon et al. 2017; Schötterl et al. 2019; Menke et al. 2019). Furthermore, we found research that Korean mistletoe lectin affected the selfrenewal activity of placenta-derived mesenchymal stem cells (MSCs) (Choi et al. 2012; Kim et al. 2019), however its therapeutic use for cancer is still insufficiently investigated (Hmadcha et al. 2020). 

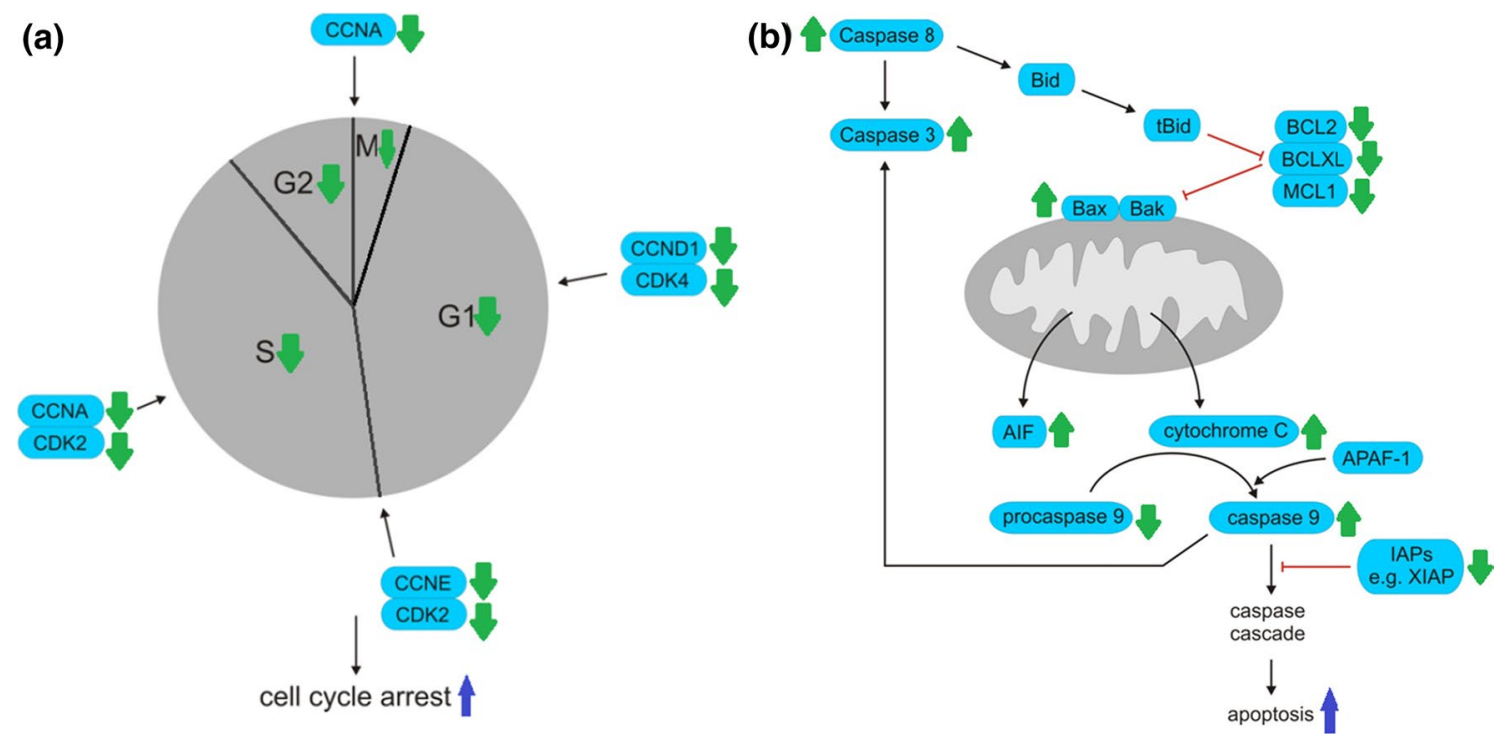

Fig. 1 Mechanism of anticancer activity of mistletoe. Mistletoe targets two important signalling pathways, PI3K/AKT and MAPK. PI3K/AKT pathway is responsible for growth and survival of cancer cells. Mistletoe induces apoptosis by inhibition of AKT phosphorylation. MAPK pathway is mediated by ERK, p38 and JNK. Mistletoe enhances p38 and JNK1 activation and reduces ERK leading to apoptosis and cell cycle arrest of cancer cells. a Mistletoe downregulates cyclins (CCND1, CCNE, CCNA) and cyclin-dependent protein kinases (CDK4, CDK2) inhibiting cell cycle. b Mistletoe upregulates proapoptotic proteins (Bax) and downregulates inhibitors of apoptosis (IAPs) such as BCL2, BCL2L1, MCL1, XIAP. Furthermore, mistletoe leads to release of cytochrome $\mathrm{c}$ and activation of caspases resulting in apoptosis

\section{Cardiac activity}

The cardiac activity of mistletoe has been confirmed in in vitro as well as in vivo studies (Committee on Herbal Medicinal Products 2012; Poruthukaren et al. 2014; Montero et al. 2016) (Table 2). Tenorio et al. (2005) and TenorioLopez et al. (2006) studied the mechanism of vasodilator activity of aqueous extract of Viscum album L. leaves on the Langendorff's isolated and perfused heart model. They showed that mistletoe induced nitric oxide syntetaze-2 (NOS-2) and nitric oxide syntetaze-3 (NOS-3) overexpression, which was connected with increases in nitric oxide (NO) and cyclic guanosine monophosphate (cGMP) production. Therefore, the vasodilator activity of mistletoe might be mediated by the NO/sGC pathway. Soluble guanylyl cyclase (sGC) is an enzyme catalysing the conversion of GTP to cGMP and mediating several biological functions, such as the inhibition of platelet aggregation, smooth muscle relaxation and vasodilation. $\mathrm{NO}$ activates $\mathrm{sGC}$ by directly binding to heme to form a ferrous-nitrosyl-heme complex. Once sGC is activated by NO, GTP to cGMP conversion is triggered. Exogenous and endogenous compounds produce vasodilation through increases in cGMP, which in turn, relaxes vascular smooth muscle cells by both desensitising the contractile apparatus to $\mathrm{Ca}^{2+}$ and lowering intracellular $\mathrm{Ca}^{2+}$, with the consequent activation of a protein known as cGMP-dependent protein kinase. NO, synthesised by the enzyme nitric oxide synthase (NOS), maintains a vasodilator tone that is essential for the regulation of blood flow and pressure. NOS is a heme-containing enzyme that has three isoforms, designated as NOS-1, NOS-2 and NOS-3 (Tenorio-Lopez et al. 2006). Furthermore, studies on myocardial ischemia and reperfusion injury in rats as well as isoproterenol-induced heart failure in rats confirmed the cardioprotective effect of Viscum album L. might be mediated by the upregulation of the NO pathway (Karagöz et al. 2016; Suveren et al. 2017). Studies of N $\omega$-nitro-L-arginine methyl ester (L-NAME)-induced hypertensive rats treated with methanolic extract of Viscum articulatum Burm. f. showed that mistletoe has an antihypertensive effect, which may be attributed to its diuretic, nephroprotective and hypolipidemic action. It was proposed the blood pressure lowering activity of this extract might have been due to the presence of triterpenoids, such as oleanolic acid and betulinic acid (Bachhav et al. 2012). Oleanolic acid isolated from the cuticular wax of Viscum articulatum Burm. f. significantly decreased the systolic blood pressures and cardiac lipid peroxidation levels in glucocorticoid (dexamethasone)-induced hypertensive rats, which might be connected with its antioxidant and nitric oxide releasing action (Bachhav et al. 2011). On the other hand, a study carried out in L-NAME-induced hypertensive rats treated with oleanolic acid showed that this compound did not affect nitric oxide levels, and its antihypertensive effect might be due to diuresis and nephroprotection (Bachhav et al. 2015). Another mechanism of the antihypertension activity of Viscum might be mediated by the calcium channel 


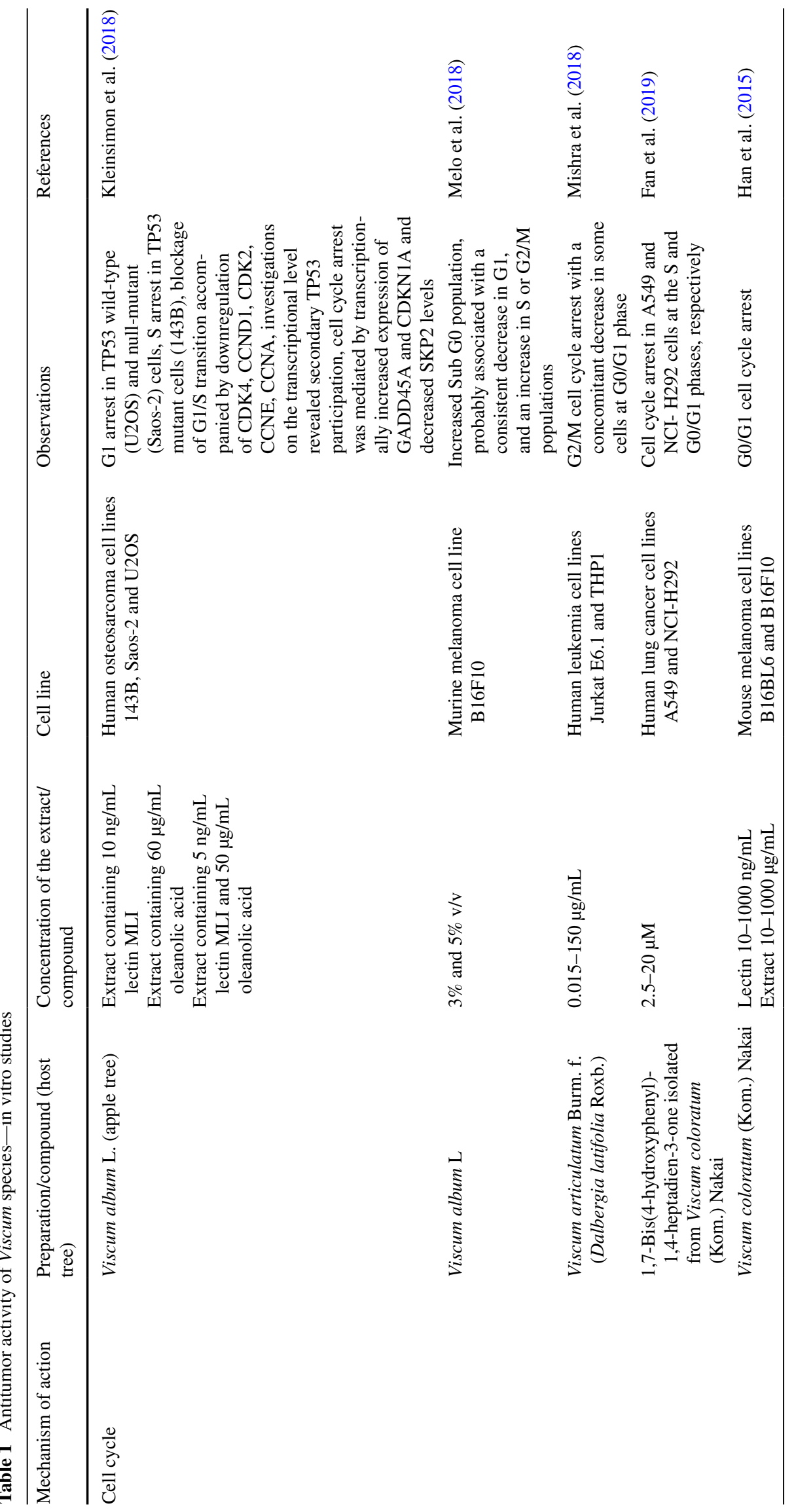




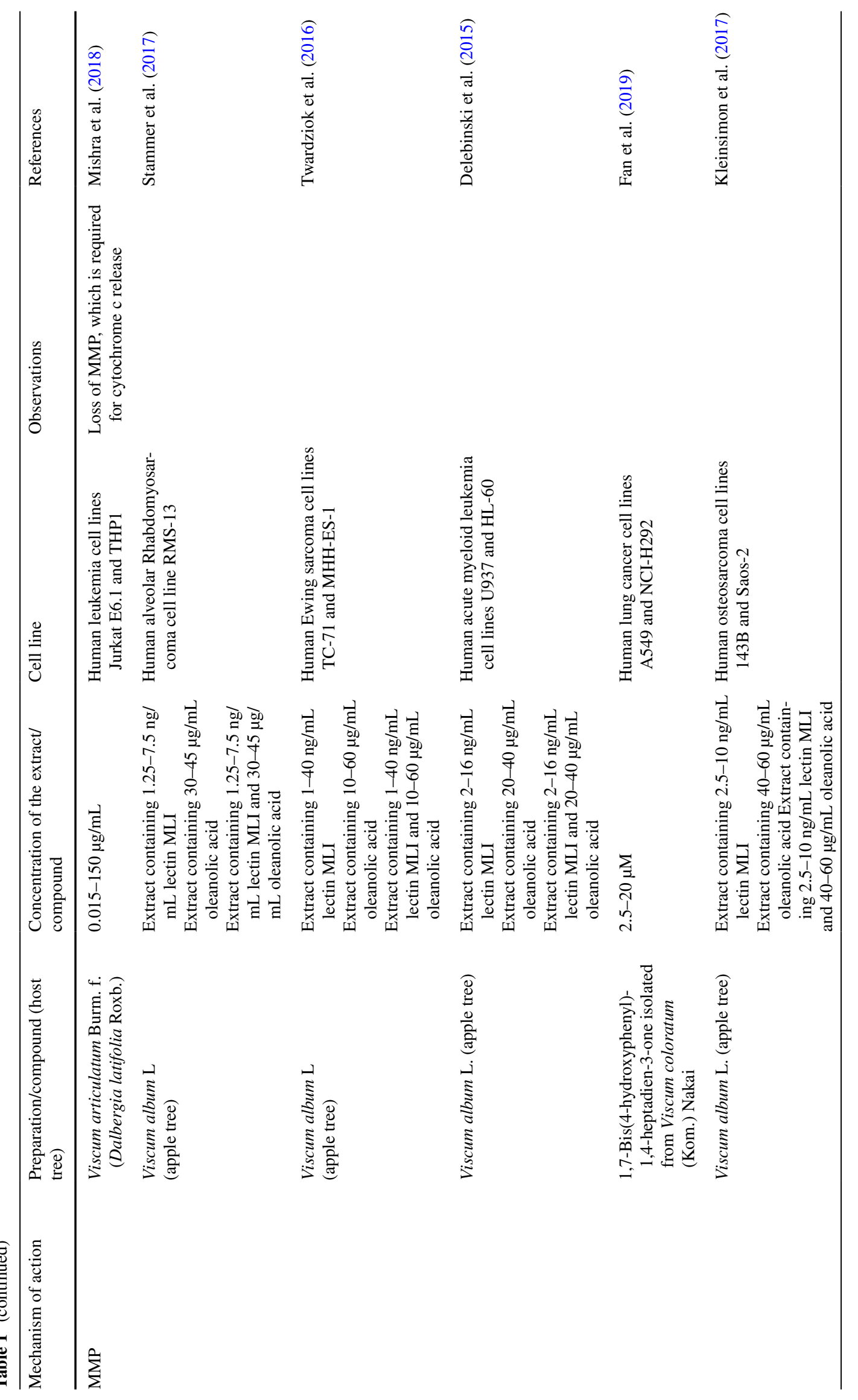




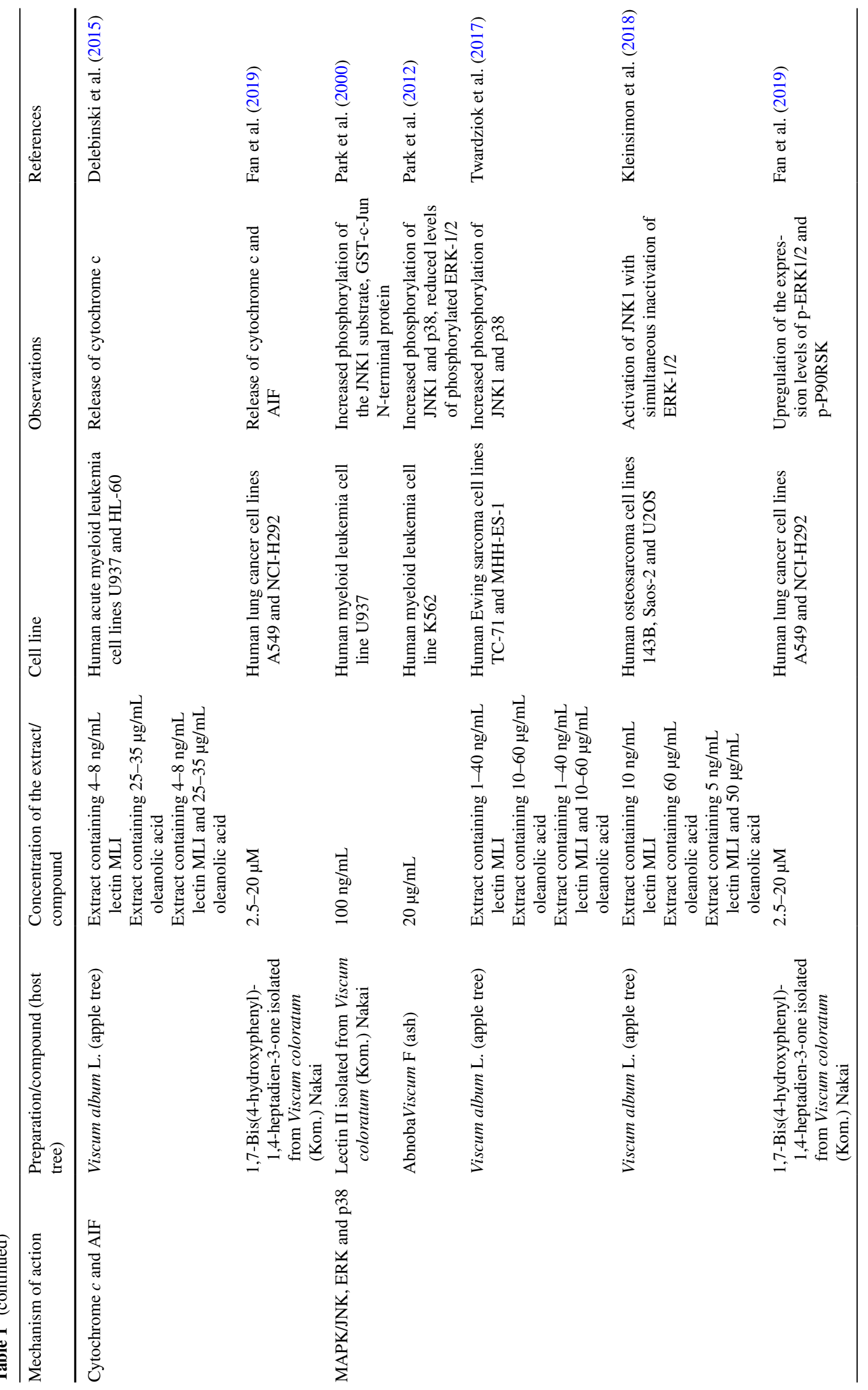




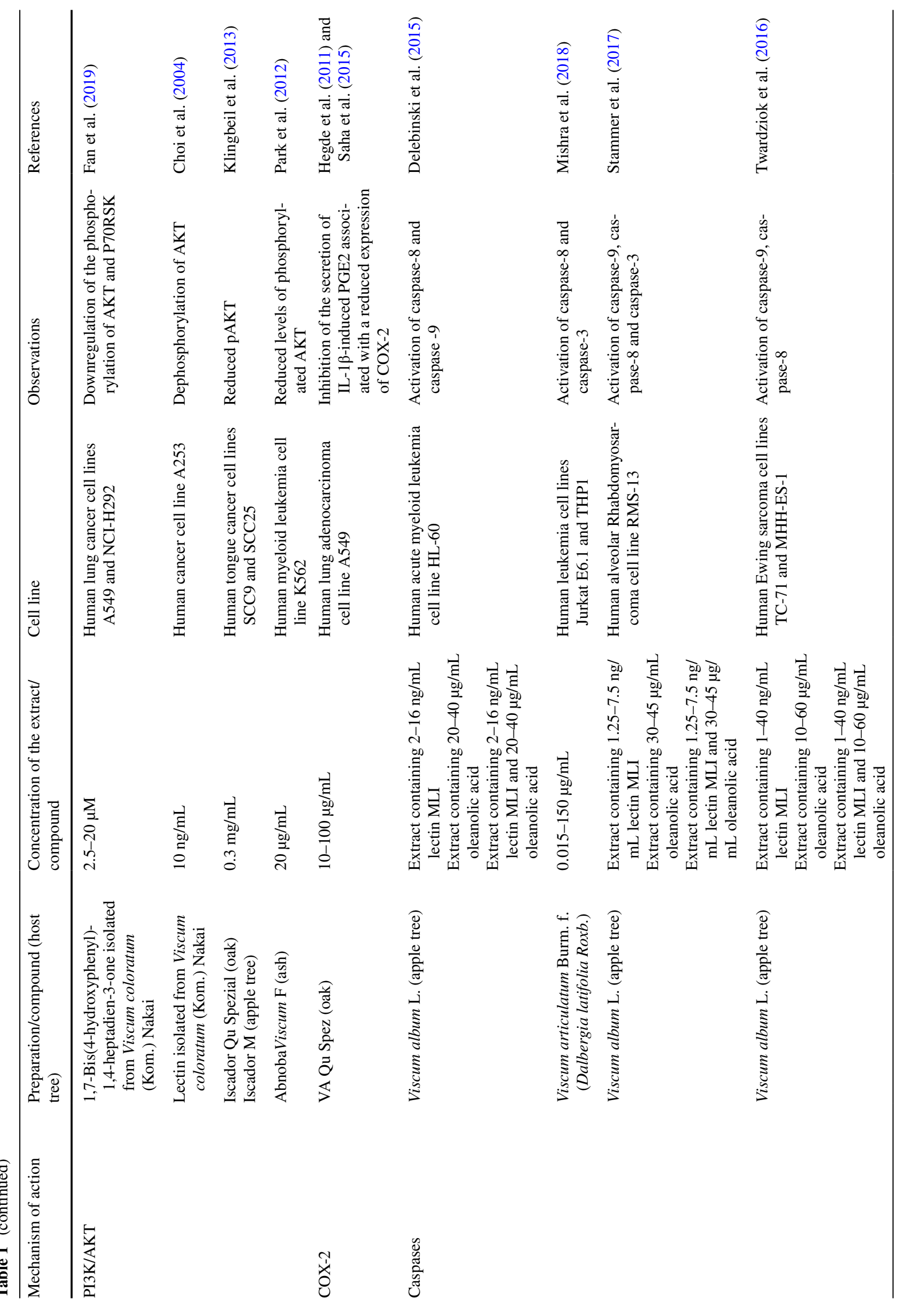




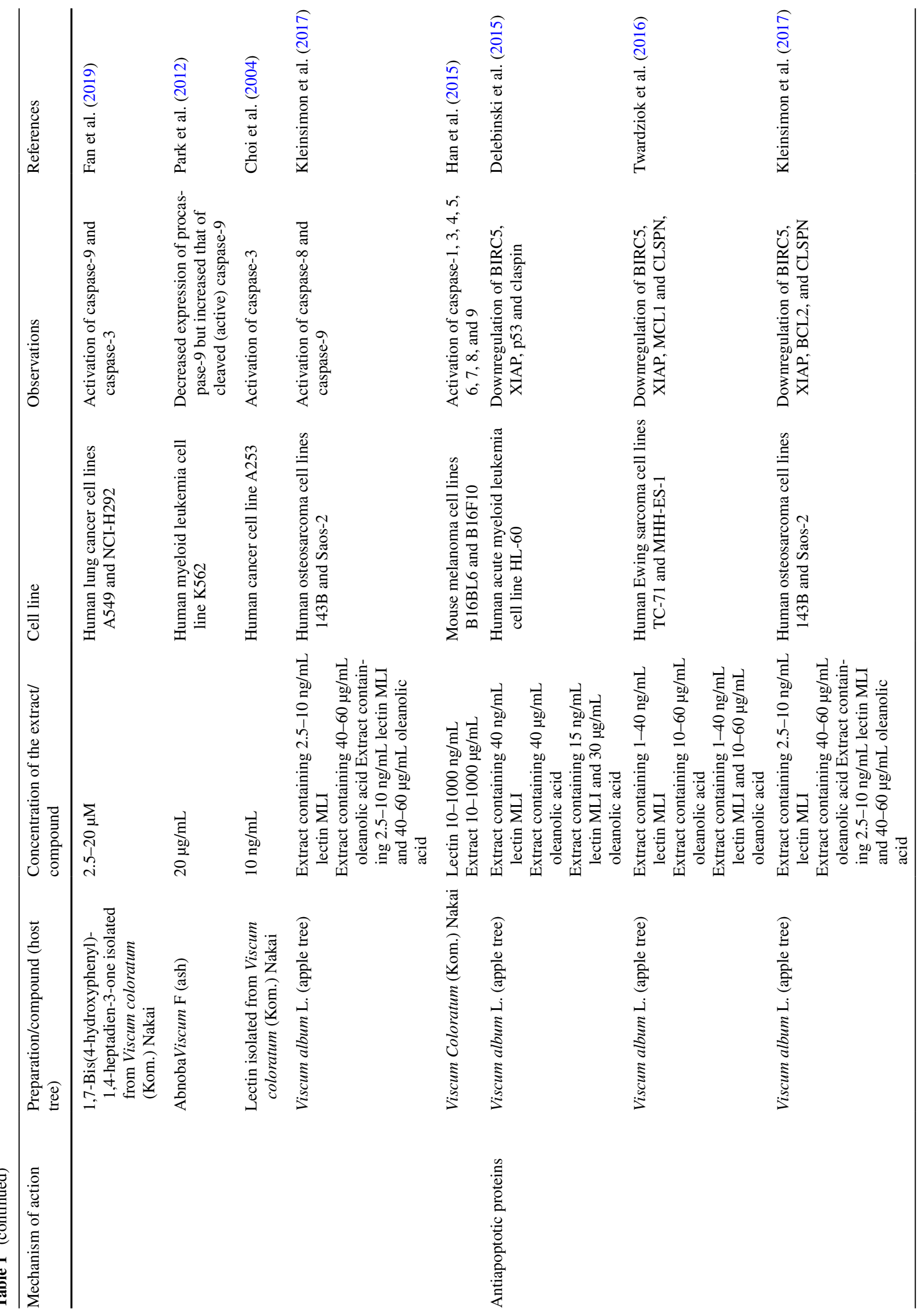




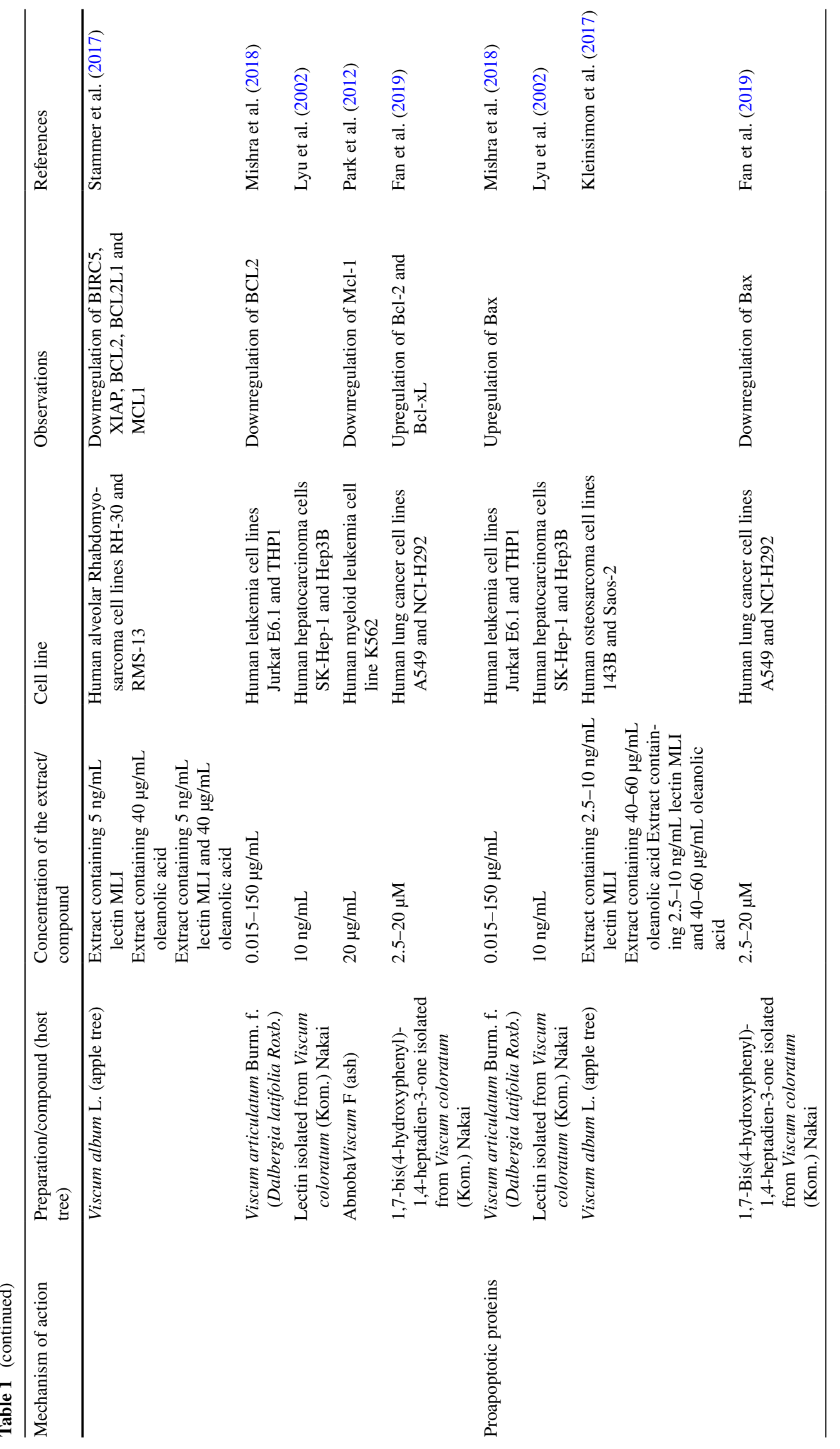




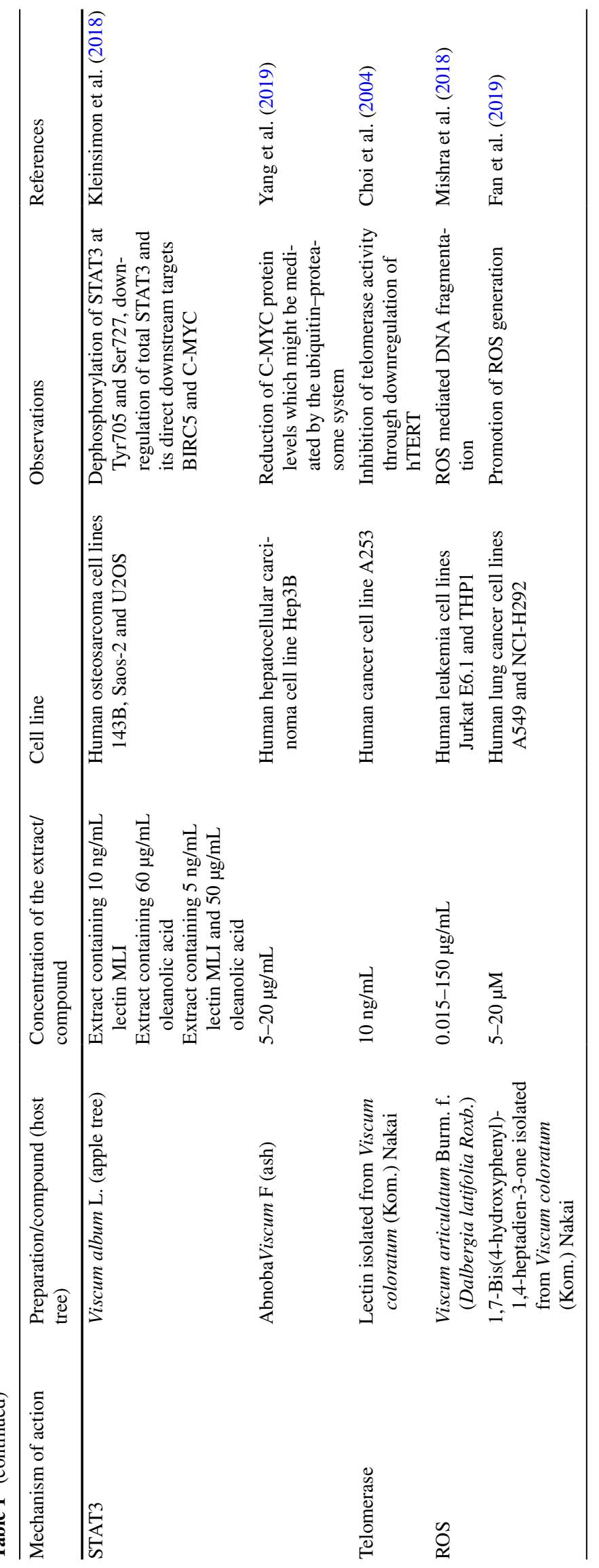




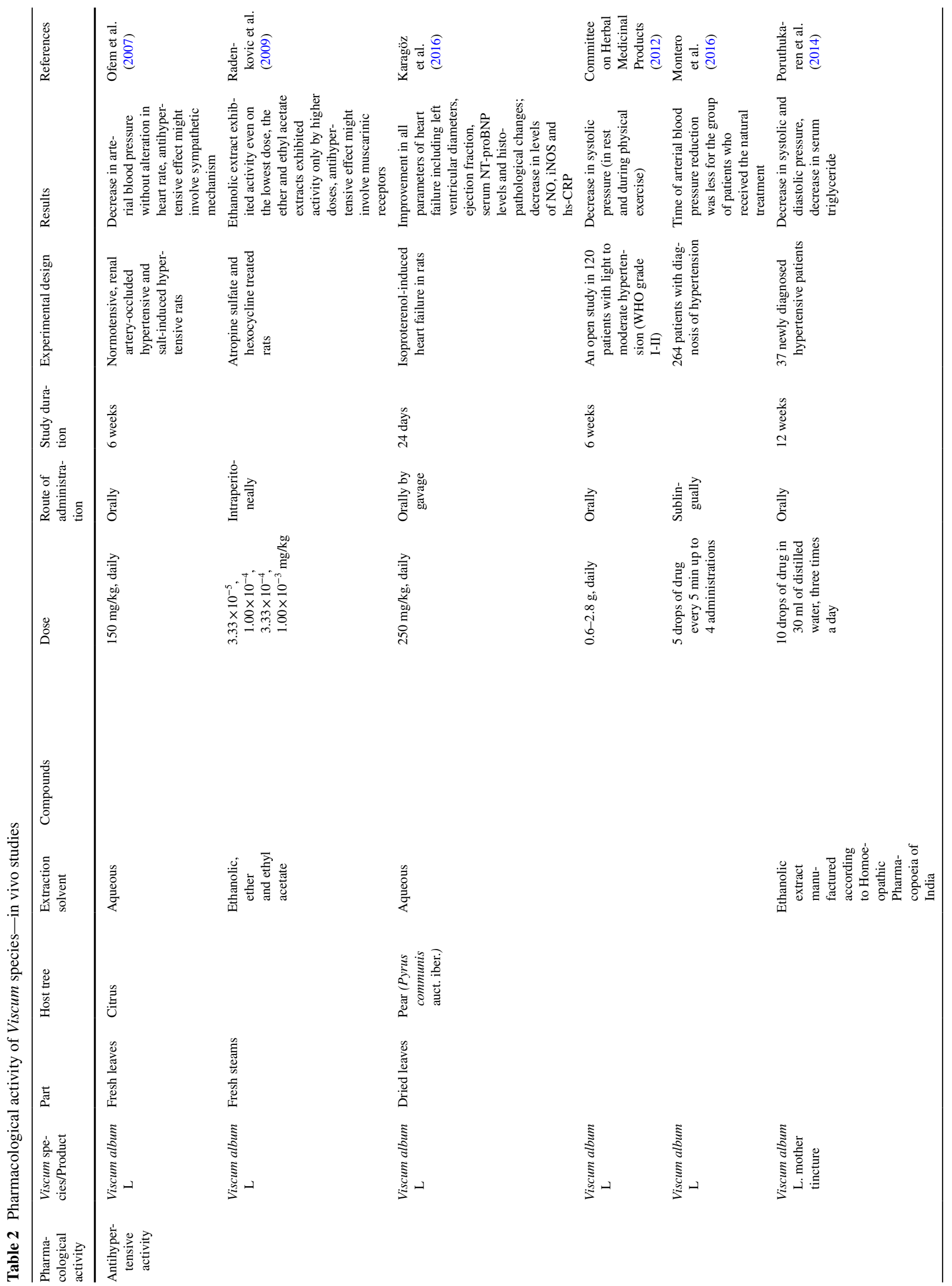




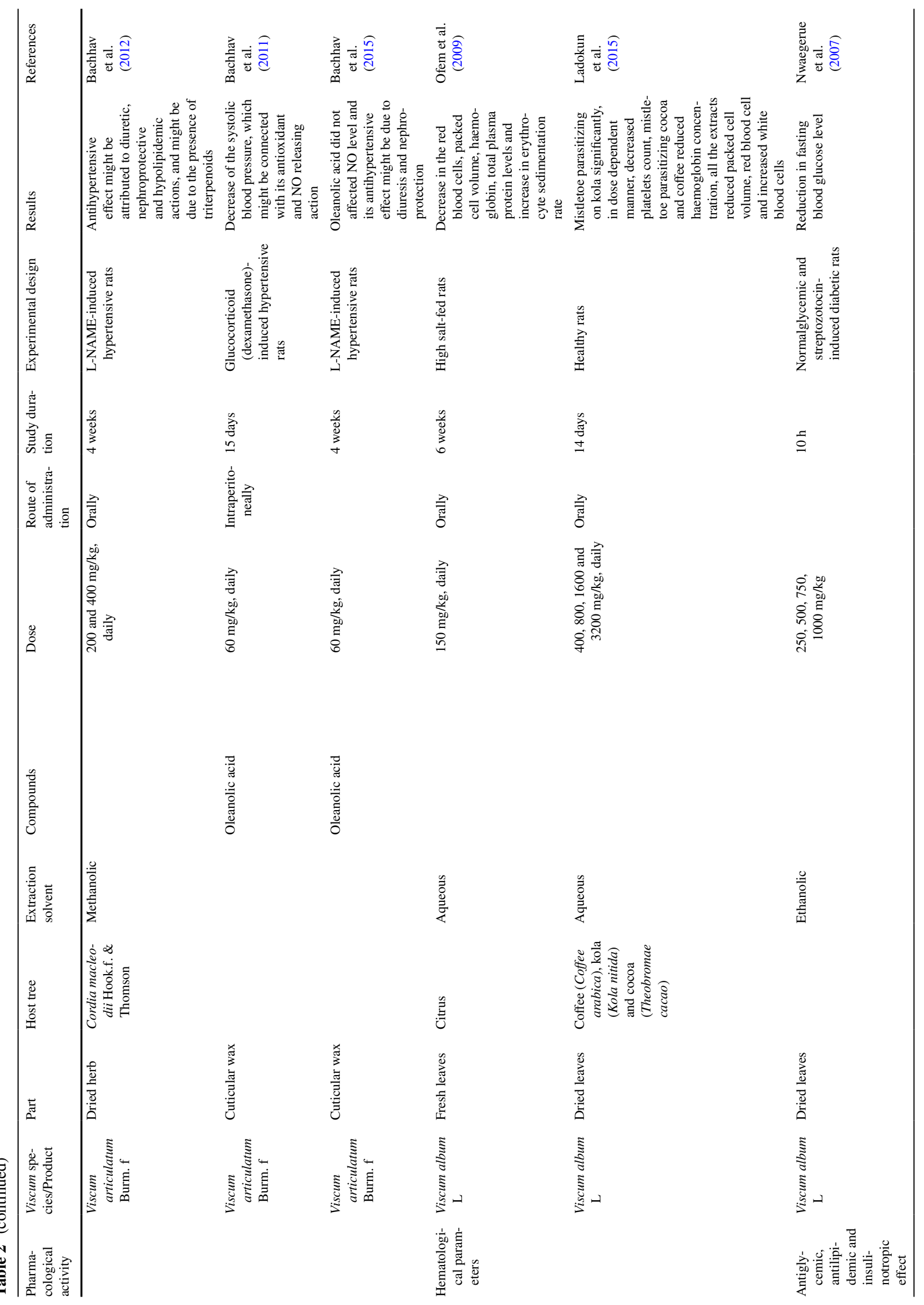




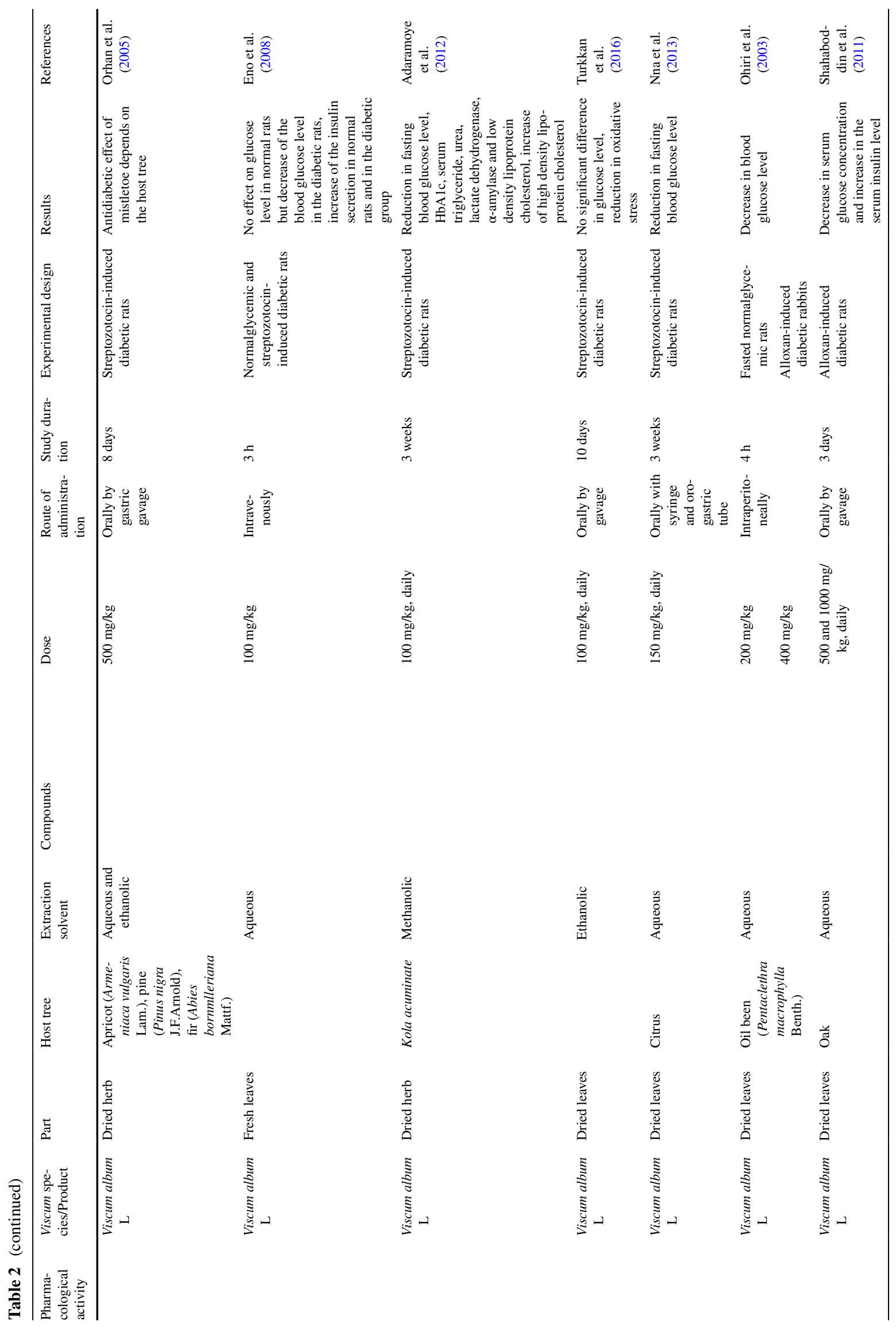




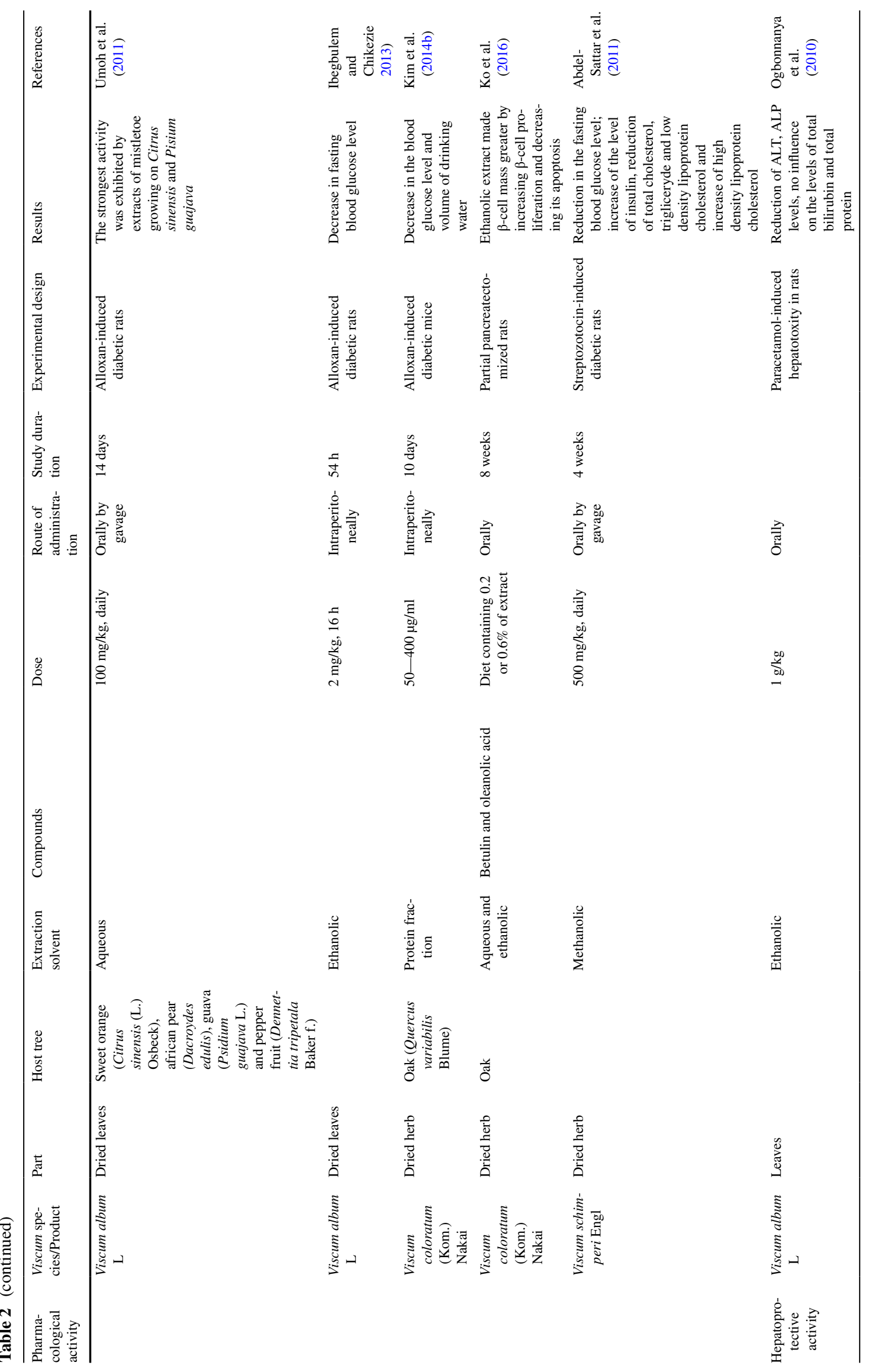




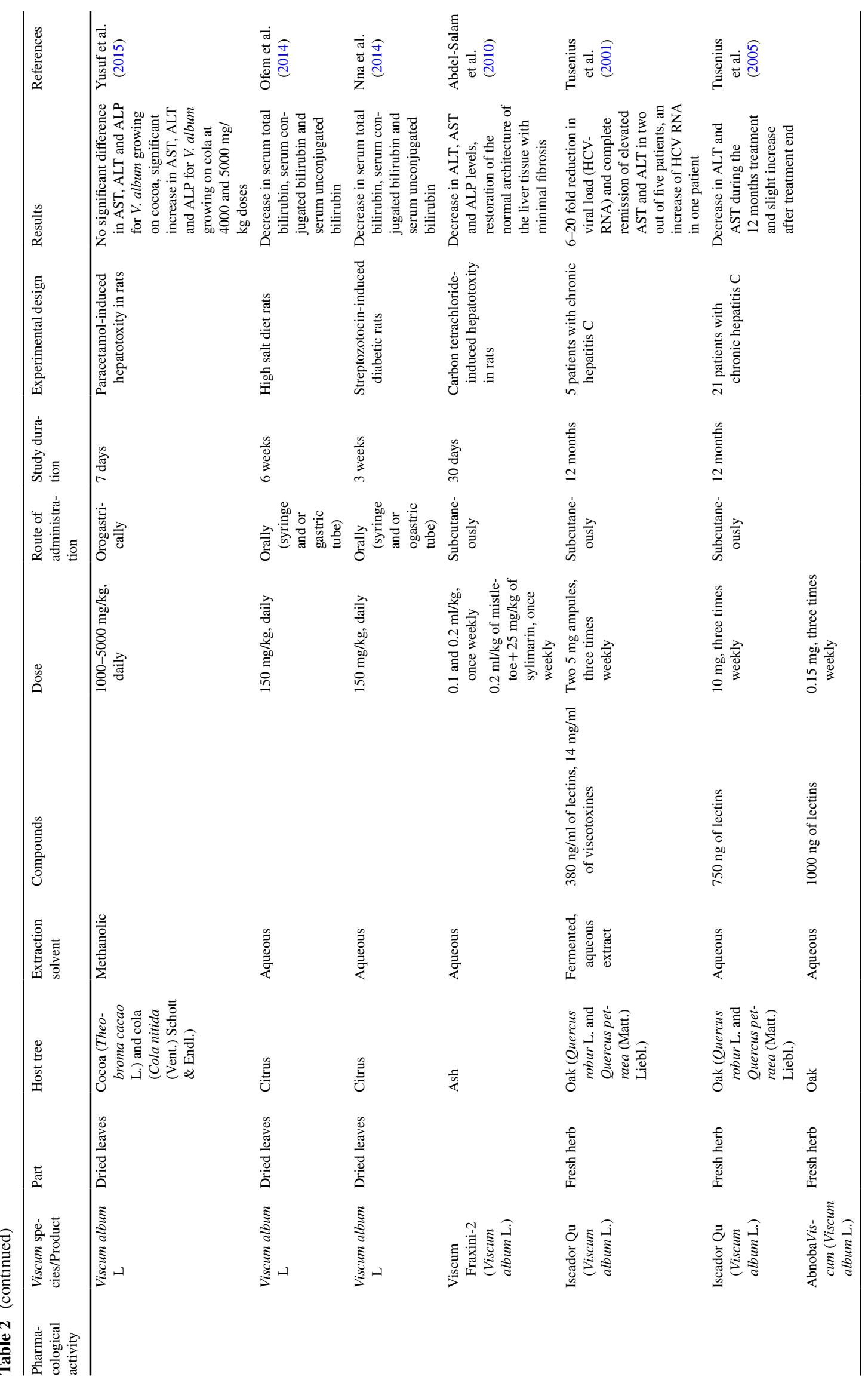




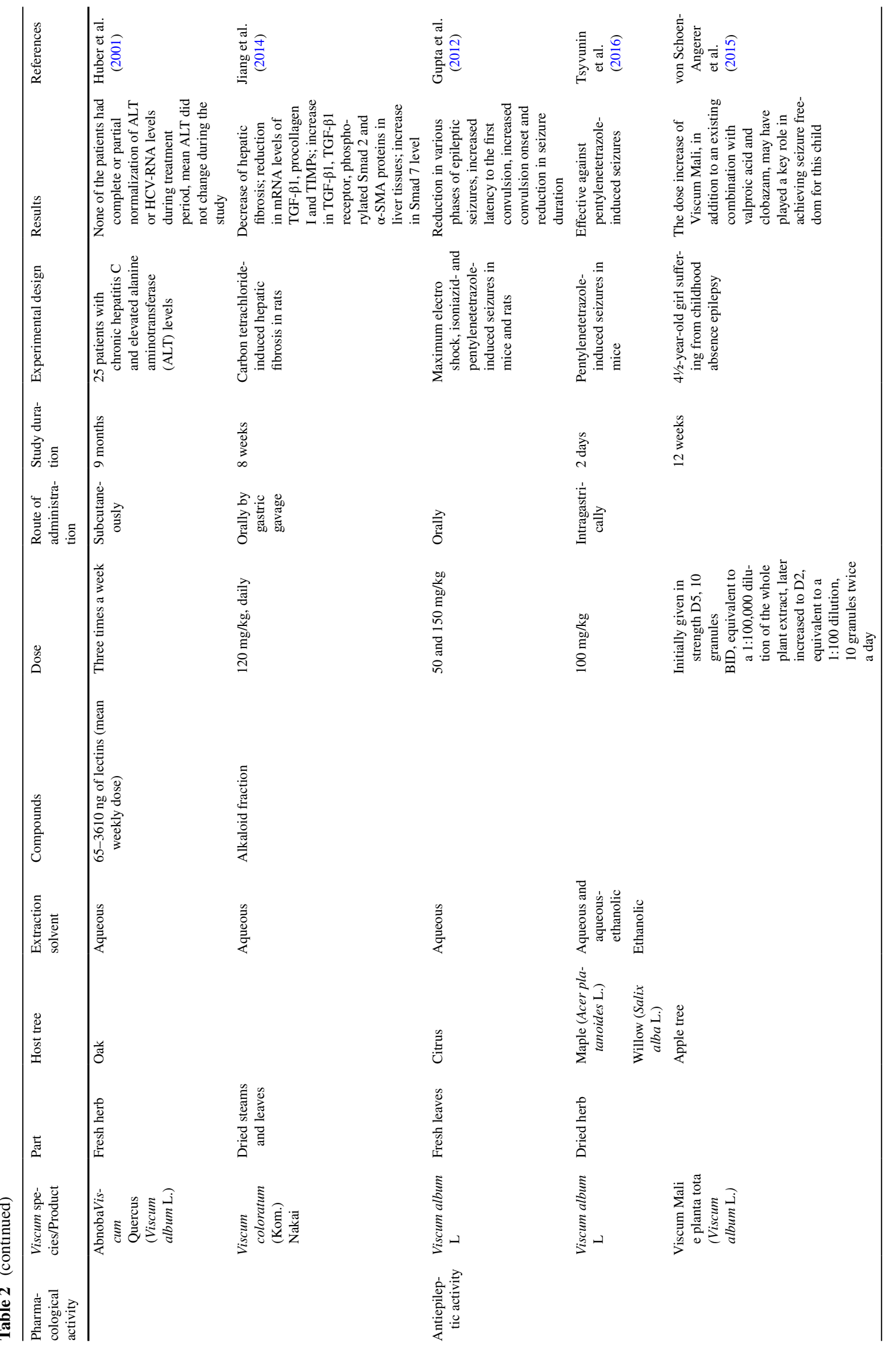




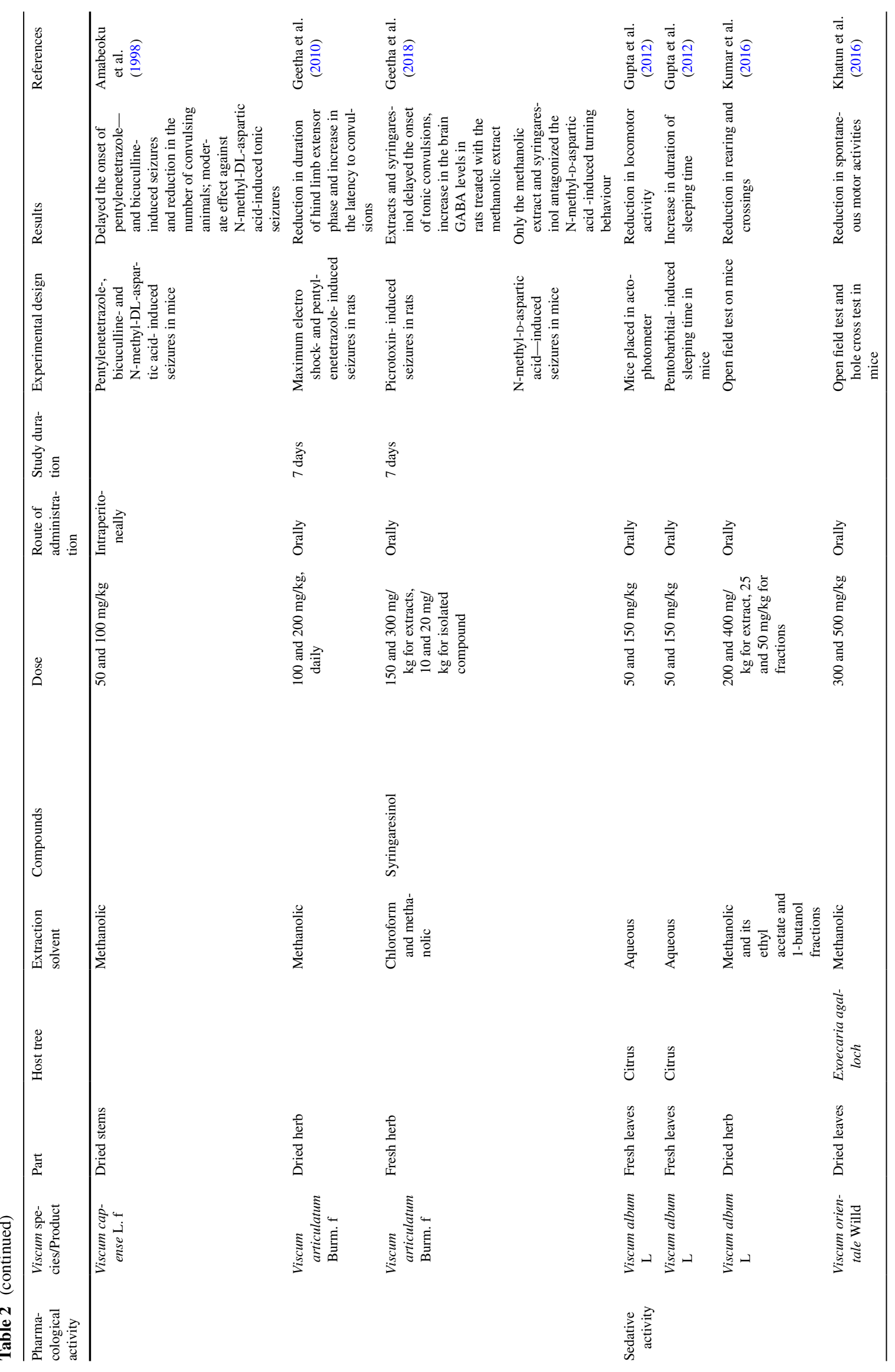




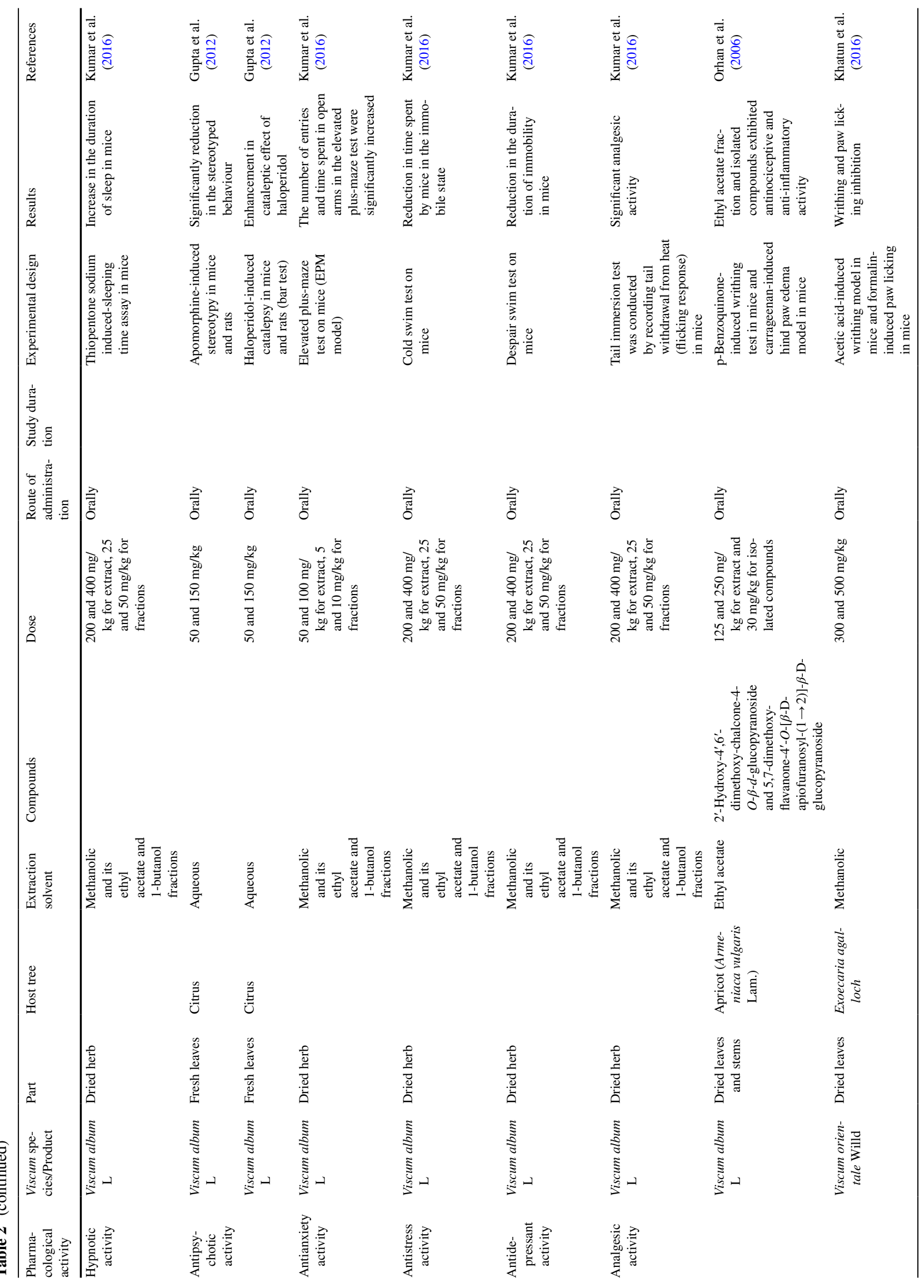




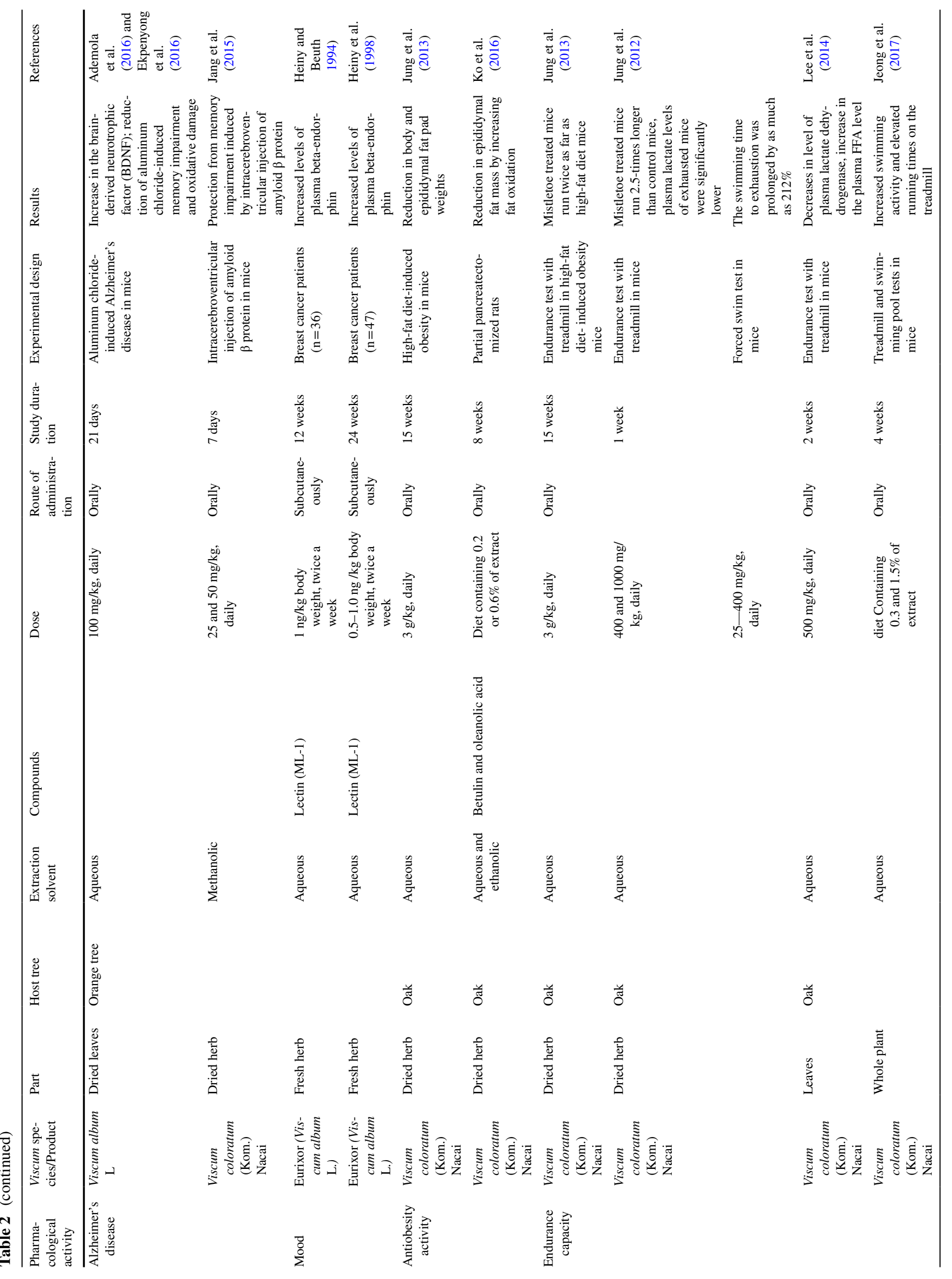




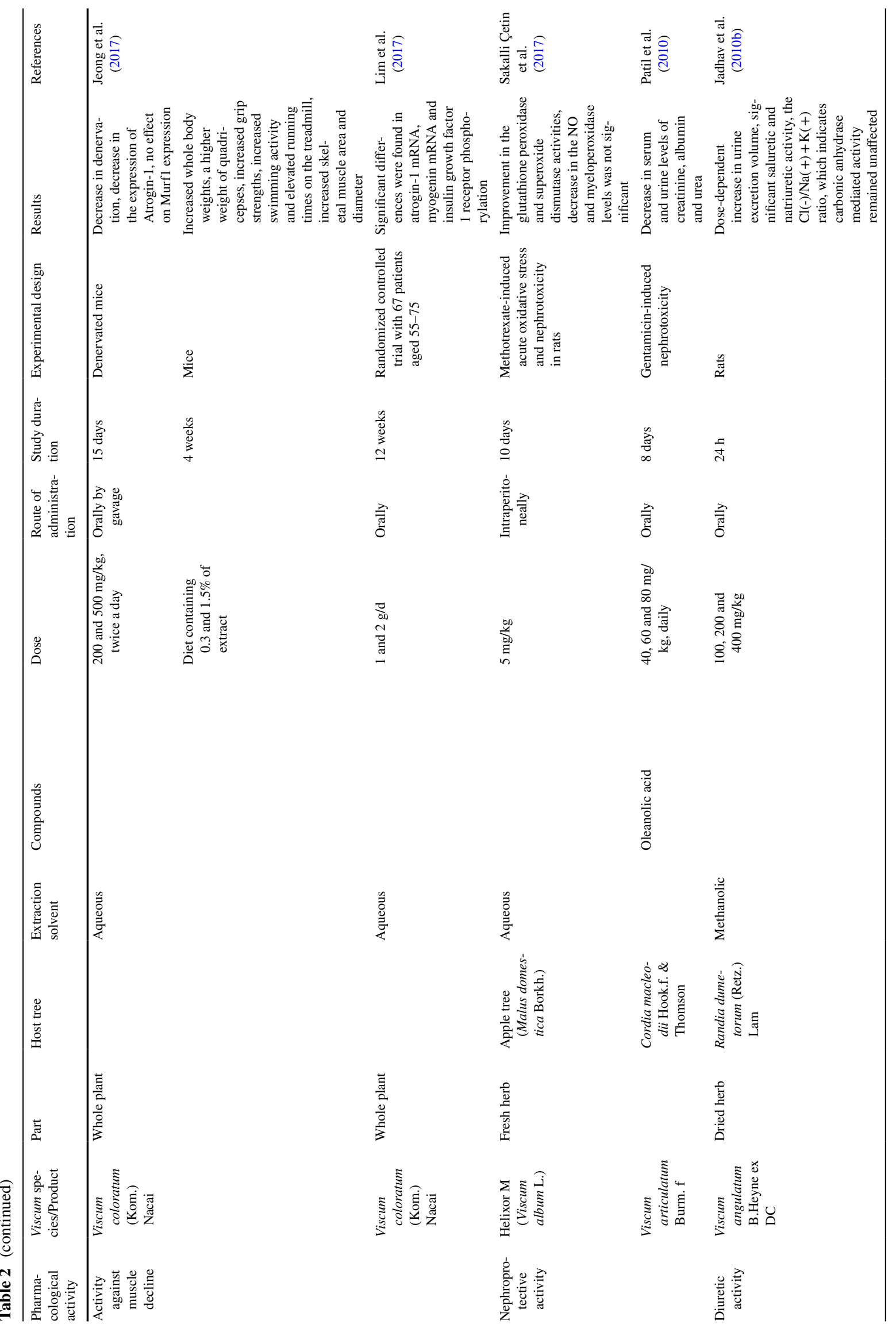




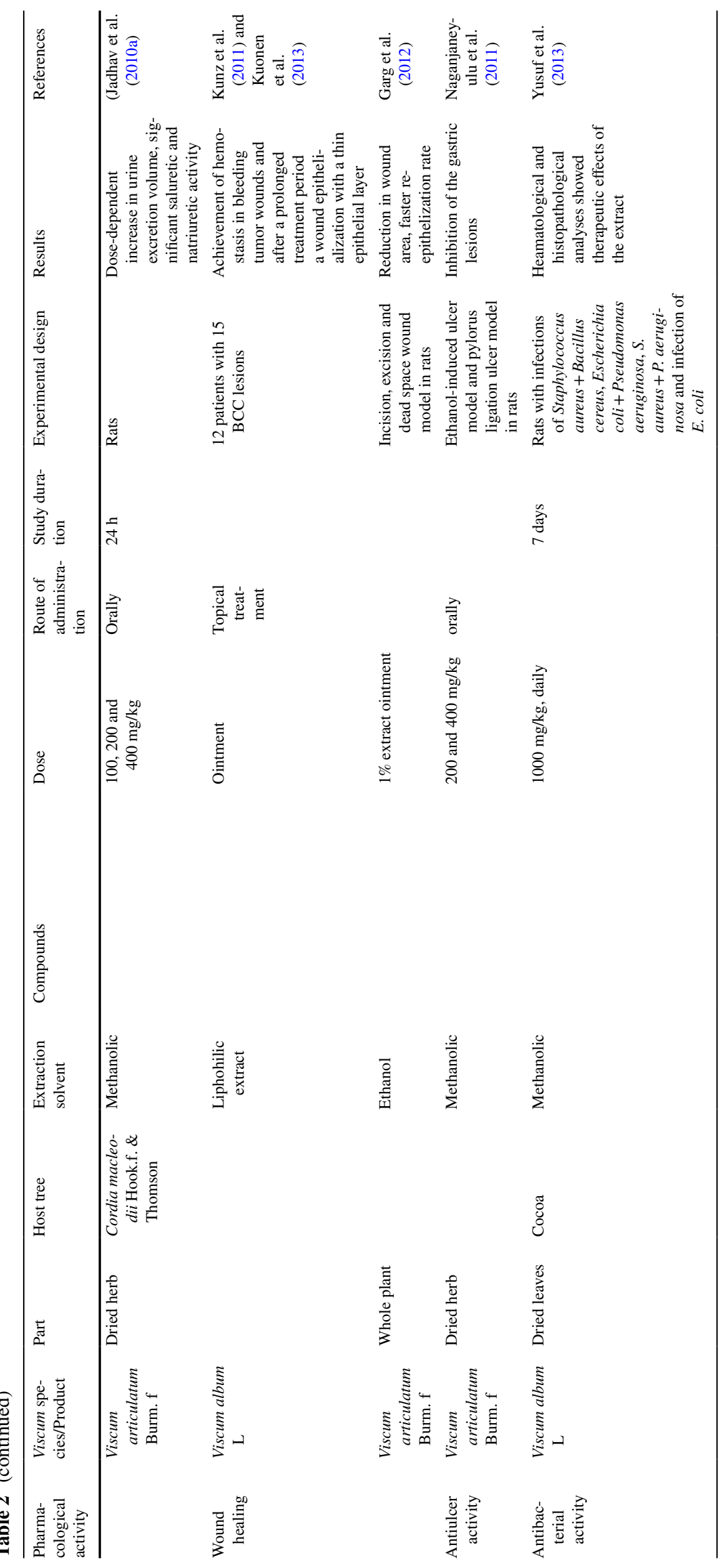


blockade (CCB). The contractile mechanism in smooth muscle is activated by a rise in the concentration of free intracellural $\mathrm{Ca}^{2+}$ concentration, which activates the contractile elements. The increase in intracellular $\mathrm{Ca}^{2+}$ occurs via either influx from the extracellular fluid through voltage-dependant $\mathrm{Ca}^{2+}$ channels (VDCs) or its release from intracellular stores. Thus, vascular smooth muscle relaxant agents may produce their effects by inhibiting either or both sources of $\mathrm{Ca}^{2+}$ (Mojiminiyi et al. 2008; Khan et al. 2016). A study carried out in rat aortic rings showed that an aqueous extract of leaves of Viscum album L. growing on oil palm trees had vasorelaxant activity, which might be mediated by a non-specific non-competitive inhibition of $\mathrm{Ca}^{2+}$ influx as well as inhibition of $\mathrm{Ca}^{2+}$ mobilization from intracellular stores (Mojiminiyi et al. 2008). Furthermore, a study carried out in rabbit aortic rings showed that vasorelaxant activity of mistletoe is mediated through a voltage-dependent $\mathrm{Ca}^{2+}$ channel blockade (Khan et al. 2016). It was proposed that some of the actions on $\mathrm{Ca}^{2+}$ influx or mobilization from cellular stores observed in the study for Viscum album L. might be partly mediated by NO. This is because NO inhibits $\mathrm{Ca}^{2+}$ influx through ligand gated $\mathrm{Ca}^{2+}$ channels as well as release from cellular stores. Thus, it is probable that Viscum album L. might achieve vasorelaxation through dual mechanisms, the $\mathrm{NO} / \mathrm{sGC}$ pathway as well as through $\mathrm{Ca}^{2+}$-dependent mechanisms (Mojiminiyi et al. 2008) (Fig. 2). Ofem et al. (2007) suggested that the reduction in blood pressure without any alteration in heart rate by aqueous extract of leaves of Viscum album L. growing on citrus may be due to catecholamine-like blocking agent(s), showing predominantly alpha-1 adrenoceptor antagonist action or agonist-like agents that may be stimulating the beta- 2 adrenoceptors to produce the depressor effect. In turn, Radenkovic et al. (2009) proposed that decreases in the blood pressure in rats treated with ethanolic extracts of Viscum album L. steams might be connected with muscarine cholinergic receptors. In rat models of myocardial infarction, flavonoids isolated from Viscum coloratum (Kom.) Nakai reduced ischemic myocardial injuries by blocking the signalling pathway of plateletactivating factor (PAF). A PAF antagonist isolated from mistletoe might be a homoeriodictyol-7- $O-\beta$-D-glucoside (Chu et al. 2008). Additionally, Viscum album L. improved haematological parameters in rats. Mistletoe extracts reduced red blood cell count and packed cell volume (Ofem et al. 2009; Ladokun et al. 2015) and brought the elevated total plasma protein levels and reduced erythrocyte sedimentation rate in the high salt-fed rats to near control levels, indicating the ability of the extract to prevent marked changes in the blood viscosity (Ofem et al. 2009).Fig. 2 Mechanism of cardiac activity of mistletoe. Mistletoe compounds acting on receptor of endothelial cell might activate influx of $\mathrm{Ca}^{2+}$ ions leading to activation of NOS. NOS catalyzes formation of NO from L-arginine. NO diffuses to smooth muscle cell. Once sGC is activated by NO, GTP to cGMP conversion is triggered. cGMP activates PKG leading to reducing intracellular $\mathrm{Ca}^{2+}$ (by inhibition of $\mathrm{Ca}^{2+}$ influx through ligand gated $\mathrm{Ca}^{2+}$ channels and release from cellular stores). Proposed mechanism is confirmed by the fact that mistletoe induces NOS- 2 and NOS-3 overexpression which is connected with increase in NO and cGMP production

\section{Antidiabetic activity}

In vivo studies on rats showed that Viscum species exhibit antiglycemic and insulinotropic activity by decreasing blood glucose level and increasing the insulin secretion (Ohiri et al. 2003; Nwaegerue et al. 2007; Eno et al. 2008; Shahaboddin et al. 2011; Abdel-Sattar et al. 2011; Adaramoye et al. 2012; Ibegbulem and Chikezie 2013; Kim et al. 2014b; Turkkan et al. 2016) (Table 2). Furthermore, the effects of mistletoe have been shown to be dependent on host trees (Orhan et al. 2005; Umoh et al. 2011). The antilipidemic activity of mistletoe was shown in the reduction in low density lipoprotein cholesterol (LDL) and the increase in high density lipoprotein cholesterol (HDL) (Abdel-Sattar et al. 2011; Adaramoye et al. 2012; Kim et al. 2015) as well as improvement of HOMA-IR (Homeostatic Model Assessment of Insulin Resistance), which is an indicator of insulin resistance (Kim et al. 2015). Gray and Flatt (1999) showed that aqueous extract of Viscum album L. exhibited dosedependent activity to stimulate insulin secretion by rat clonal pancreatic $\beta$-cells, and the effect was not mediated by lectins. Furthermore, Kim et al. (2014b) showed that Korean mistletoe growing on oak increased the insulin secretion from the rat pancreatic $\beta$-cells (RINm5F cells) without any effects of cytotoxicity. The lectin-free protein fraction induced insulin secretion was similar to the Korean mistletoe extract. It was also reported that the protein fraction upregulated pancreatic and duodenal homeobox 1 (PDX-1) and beta2 (neuroD), which are transcription factors regulating the expression of insulin gene. An ethanolic extract of Korean mistletoe growing on oak also made $\beta$-cell mass greater by increasing $\beta$-cell proliferation and decreasing its apoptosis. An in vitro study showed that betulin potentiated insulin-stimulated glucose uptake by increasing PPAR- $\gamma$ (peroxisome proliferator-activated receptor $\gamma$ ) activity and insulin signalling in 3T3-L1 adipocytes, whereas oleanolic acid enhanced glucose-stimulated insulin secretion and cell proliferation in insulinoma cells (Ko et al. 2016). Aqueous Viscum coloratum (Kom.) Nakai extract significantly increased the secretion of insulin and an insulin precursor, C-peptide, by RINm5F cells. In differentiated $\mathrm{C} 2 \mathrm{C} 12$ cells, the extract enhanced the expression of glucose transporter type 4 (GLUT-4), insulin receptor substrate 1 (IRS-1), and protein kinase B (AKT), which are involved in the glucose uptake signalling pathway. Viscothionin, a polypeptide isolated from mistletoe, increased the level of insulin secretion by more than 20 -fold compared to 
Fig. 3 Mechanism of antidiabetic activity of mistletoe. Mistletoe increases the secretion of insulin and insulin precursor, C-peptide. Insulin binds to tyrosine kinase receptor (RTK). The activated receptor phosphorylates the IRS-1 protein leading to activation of PI3K which catalyzes the addition of phosphate group to PIP2, converting it to PIP3. PIP3 activates PDK1 leading to AKT phosphorylation, recruitment of the glucose transporter GLUT-4 to the membrane and glucose inflow. Mistletoe enhances the expression of GLUT-4, IRS-1 and AKT. Furthermore, protein fraction of mistletoe upregulates transcription factors PDX-1 and beta2 (neuroD). PDX-1 and beta2 become phosphorylated (this process might be mediated by PI3K and ERK1/2 pathways) and regulate insulin gene transcription
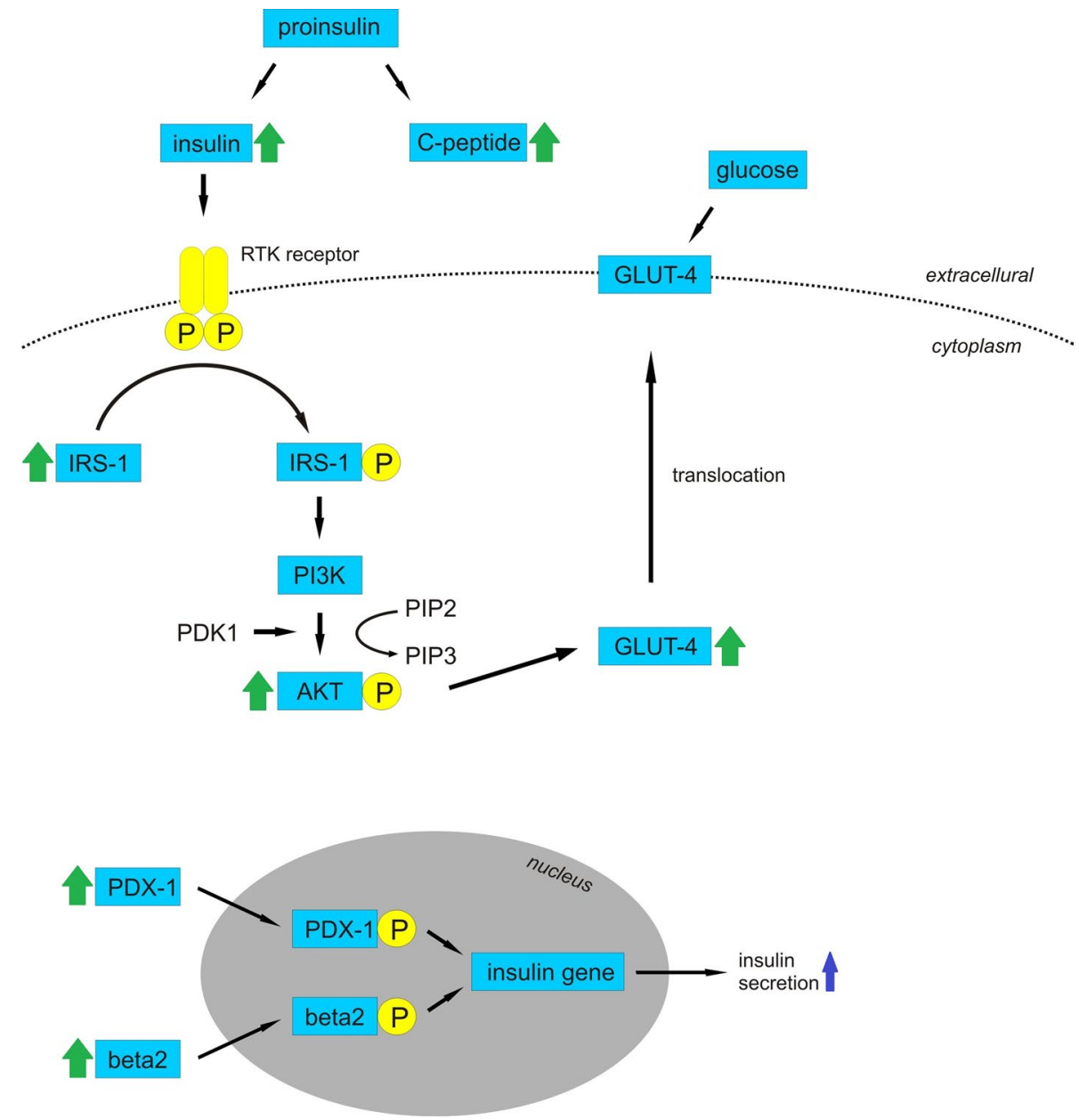

that induced by the extract (Park et al. 2019). Furthermore, it was reported that mistletoe extracts inhibited $\alpha$-glucosidase activity, an enzyme catalysing the cleavage of glucose from disaccharide, impeding the digestion and adsorption of glucose, eliciting attenuated postprandial plasma glucose levels (Önal et al. 2005; Park et al. 2019). The mechanism of action is shown on Fig. 3.

\section{Hepatoprotective activity}

Indicators of liver cell injury are increased levels of serum aminotransferases, alanine aminotransferase (ALT) and aspartate aminotransferase (AST) as well as alkaline phosphatase (ALP). Studies on rats with hepatic damage showed that Viscum species decreased levels of ALT, AST and ALP (Abdel-Salam et al. 2010; Ogbonnanya et al. 2010; Yusuf et al. 2015) (Table 2). Furthermore, aqueous extracts of leaves of Viscum album L. growing on citrus decreased levels of serum bilirubin in high-salt-fed rats and in streptozotocin-induced diabetic rats (Nna et al. 2014; Ofem et al. 2014). The results of studies on patients with chronic hepatitis $\mathrm{C}$ were ambiguous. Treatment with either Iscador or AbnobaViscum caused significant improvement for AST and ALT (Tusenius et al. 2005). Furthermore, in two out of five patients treated with Iscodar, a 6-20 fold viral load reduction (HCV-RNA) and improvements for AST and ALT were observed (Tusenius et al. 2001). On the other hand, none of the patients with chronic hepatitis $\mathrm{C}$ and elevated ALT levels had complete or partial normalization of ALT or HCV-RNA levels during treatment with AbnobaViscum Quercus (Huber et al. 2001). The mechanism of hepatoprotection by mistletoe is not clear, but it might be mediated by the TGF- $\beta$ /Smad pathway (Fig. 4). It is accepted that hepatic fibrosis is characterized by an excessive accumulation of extracellular matrix (ECM) proteins. Transforming growth factor- $\beta 1$ (TGF- $\beta 1$ ) is a cytokine leading to the activation of hepatic stellate cells (HSCs), and it stimulates ECM production while inhibiting its degradation. Once activated, TGF$\beta 1$ binds its cognate receptors and functions in autocrine and paracrine manners to exert its activities via Smad-dependent and -independent pathways. Smads are signal transduction molecules transmitting signals directly from cell surface receptors to the nucleus. Smad signal transduction pathways 
Fig. 4 Mechanism of hepatoprotective activity of mistletoe, TGF $\beta /$ Smad pathway. TGF $\beta 1$ binds to its receptor, which consists of two type I and two type II subunits. Type II subunit phosphorylates type I subunit, which then phosphorylates Smad 2 and Smad 3. Phosphorylated Smad 2 and Smad 3 bind with Smad 4 and together they move into the nucleus to regulate expression of target genes. Smad 7 is an inhibitory Smad that negatively regulates Smad 2/3 activation. In vivo study showed that mistletoe alkaloid fractions downregulate TGF- $\beta 1$, TGF- $\beta 1$ receptor, phosphorylated Smad 2 and $\alpha$-SMA proteins as well as downregulate the mRNA levels of TGF- $\beta 1$, collagen I and TIMP-1. In contrast, Smad 7 level is upregulated. In vitro study showed that mistletoe alkaloid fractions induce Smad 7 expression and inhibit the expression of $\alpha$-SMA, TGF $\beta 1$, TGF- $\beta 1$ receptor, Smad 2 and TIMP-1

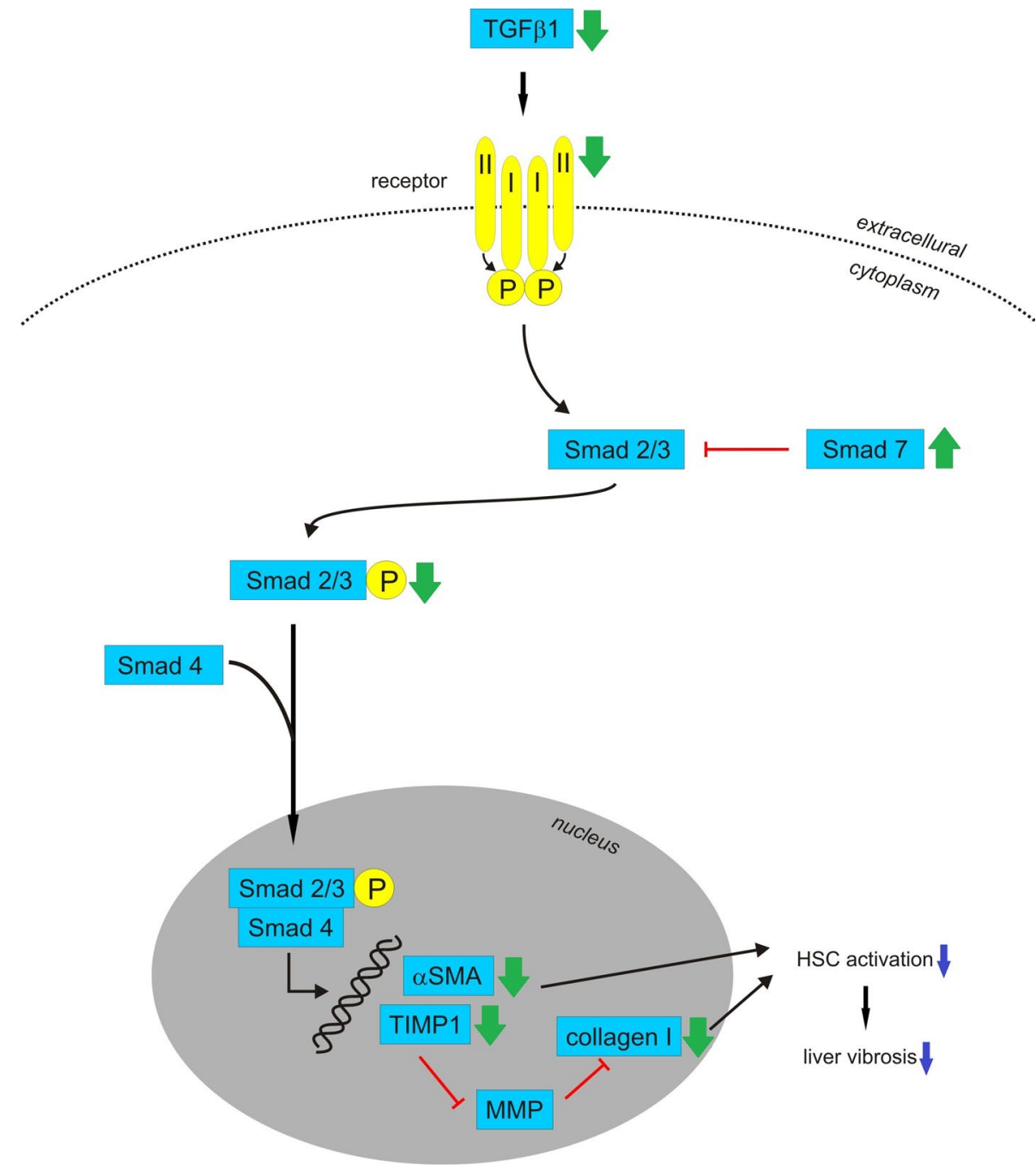

are thought to mediate TGF- $\beta 1$-induced collagen synthesis and to play a crucial role in the process of liver damage. Nine Smads have been reported and classified into three groups. When TGF- $\beta 1$ binds to its receptor, Smad $2 / 3$ is phosphorylated and binds with Smad 4, and they move together into the nucleus for translation and expression of the target gene. Smad 7 is an inhibitory Smad that negatively regulates Smad $2 / 3$ activation and functions by targeting the TGF- $\beta 1$ receptor. An in vivo study on rats with carbon tetrachlorideinduced hepatotoxicity showed that TGF- $\beta 1$, TGF- $\beta 1$ receptor and phosphorylated Smad 2 protein levels were reduced and Smad 7 level was increased after treatment with mistletoe alkaloid fractions. The mRNA levels of collagen I and tissue inhibitors of metalloproteinases (TIMP-1) were also downregulated. Collagen I is the prototype constituent of the fibril-formatting matrix in fibrotic liver, whereas TIMP-1 is an endogenous inhibitor of the matrix metalloproteinase (MMP) degradation of ECM. Furthermore, the mistletoe alkaloid fractions blocked $\alpha$-SMA ( $\alpha$ smooth muscle actin), the marker of activated HSC. An in vitro study on HSC-T6 cells showed that treatment with mistletoe alkaloid fractions induced Smad 7 expression and inhibited the expression of $\alpha$-SMA, TGF $\beta 1$, TGF- $\beta 1$ receptors, Smad 2 and TIMP-1 (Jiang et al. 2014).

\section{Neuropharmacological activity}

The influence of Viscum species on the central nervous system (CNS) is differential, and it was reviewed by Szurpnicka et al. (2019) In vivo studies on mice and rats showed that Viscum species exhibited antiepileptic (Amabeoku et al. 1998; Geetha et al. 2010, 2018; Gupta et al. 2012; Tsyvunin et al. 2016), sedative (Gupta et al. 2012; Khatun et al. 2016; Kumar et al. 2016), analgesic (Orhan et al. 2006; Khatun et al. 2016), antianxiety, antidepressant, hypnotic, anti-stress (Kumar et al. 2016) and antipsychotic activity (Gupta et al. 2012) (Table 2). Several studies have proposed that the CNS activity of mistletoe is mediated by GABA ( $\gamma$-aminobutyric acid) receptors. GABA is the most important inhibitory 


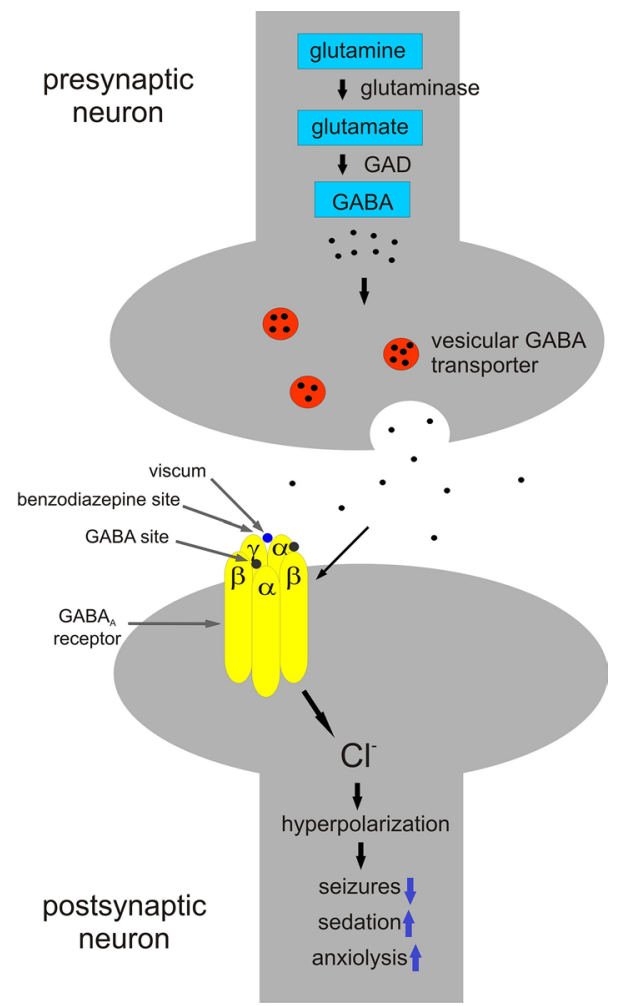

Fig. 5 Mechanism of neuropharmacological activity of mistletoe, GABAergic signalling. Mistletoe compounds might be positive allosteric modulators of $\mathrm{GABA}_{\mathrm{A}}$ receptor. They might bind to benzodiazepine site increasing the binding affinity of the receptor for GABA. This results in increased frequency of chloride ion channel opening, increased influx of chloride ions and hyperpolarization leading to anticonvulsant, sedative and anxiolytic activity

neurotransmitter in the human central nervous system. GABA is involved in epilepsy, sedation and anxiolysis, and it works by binding to $\mathrm{GABA}_{\mathrm{A}}$ receptors. $\mathrm{GABA}_{\mathrm{A}}$ receptors are heteromeric GABA-gated chloride channels. The transmembrane ion channel is opened by a stimulus generated by GABA, which allows an influx of chloride ions. This results in a decrease of the depolarizing effects of an excitatory input, thereby depressing excitability. As a result, the cell is inhibited and an anticonvulsant, sedative or anxiolytic activity is achieved. The type of activity obtained depends on the subtype of the receptor. The $\mathrm{GABA}_{\mathrm{A}}$ receptor consists of five subunits, made up of two $\alpha$, two $\beta$ and one $\gamma$ or $\delta$ subunit. Several isoforms exist $(\alpha 1-\alpha 6, \beta 1-\beta 3, \gamma 1-\gamma 3, \delta)$, potentially giving a vast number of combinatorial mixes. However, only ten subunit combinations make up the physiologically relevant $\mathrm{GABA}_{\mathrm{A}}$ receptors in the brain (Jäger and Saaby 2011). In addition to GABA binding sites, the $\mathrm{GABA}_{\mathrm{A}}$ receptor possesses binding sites for compounds that allosterically modify the chloride channel gating of GABA, such as benzodiazepines and barbiturates. Benzodiazepine site agonists increase the GABA-induced chloride

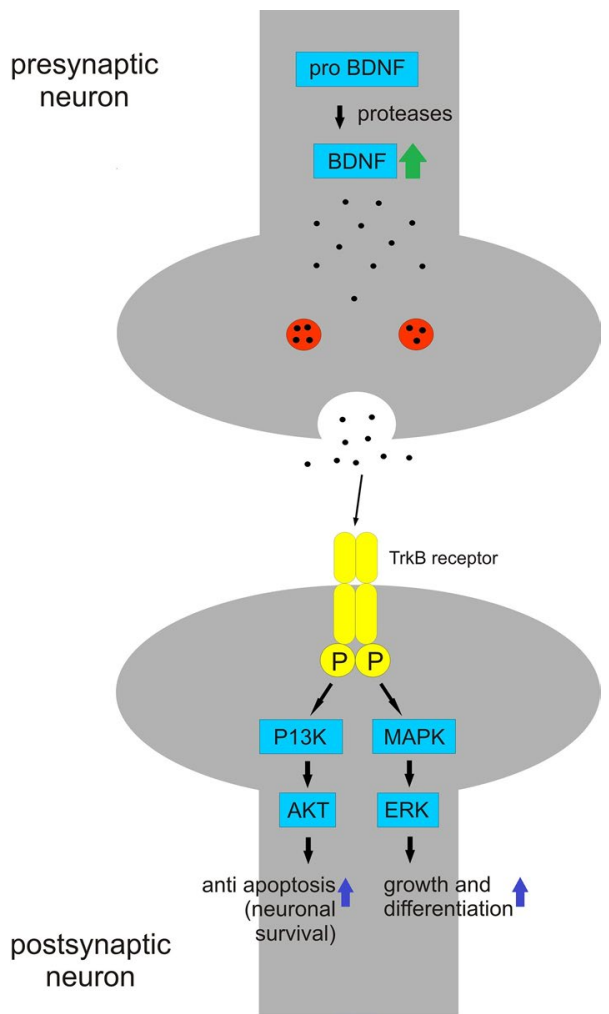

Fig. 6 Mechanism of neuropharmacological activity of mistletoe, BDNF signalling. Mistletoe has been reported to increase brainderived neurotrophic factor (BDNF) level. BDNF binds to tyrosine receptor kinase $\mathrm{B}$ leading to its phosphorylation and activation of signaling pathways. The P13K pathway activates AKT leading to neuronal survival whereas MAPK/ERK pathway leads to neuronal growth and differentiation

channel opening frequency and have established efficacy in the treatment of anxiety, insomnia and epilepsy as well as muscle relaxant, sedative, hypnotic, and cognition impairing effects (Diniz et al. 2015) (Fig. 5). Furthermore, it has been reported that mistletoe extract standardized for galactosidespecific lectin (ML-1) increases the beta-endorphin plasma levels in breast cancer patients (Heiny and Beuth 1994; Heiny et al. 1998). Endorphins act through opiate receptors. Three major type of opioid receptors have been identified, mu $(\mu)$, delta $(\delta)$ and kappa $(\kappa)$. Beta-endorphin has a relatively high affinity at mu and delta receptors. $\mathrm{Mu}(\mu)$ (agonist morphine) receptors are responsible for supraspinal analgesia, respiratory depression, euphoria, sedation, decreased gastrointestinal motility and physical dependence (Sharma et al. 2015). Treatment with an aqueous extract of Viscum album L. might also increase brain-derived neurotrophic factor (BDNF) (Ademola et al. 2016; Ekpenyong et al. 2016). BDNF plays a prominent role in modulating cognition and memory. BDNF is a neurotrophin that belongs to a family of proteins that promote the survival, functions and development of neurons. BDNF enhances neurogenesis 
Fig. 7 Probable mechanism of antiobesity activity of mistletoe. LPL converts triacylglycerides into free fatty acids. Free fatty acids are moved into the cell and activated to acyl-CoA. CPT1 converts acyl-CoA to acylcarnitine, which is transported into the mitochondria by CAT. CPT2 converts acylcarnitine back to acyl-CoA, and then acyl-CoA enters $\beta$-oxidation pathway. Acetyl-CoA goes into TCA cycle. Citrate exits mitochondria and is converted to acetyl-CoA, which is carboxylated to malonyl-CoA by ACC. FAS undergoes the reductive synthesis of palmitate which is converted to palmitiylCoA leading to formation of triacylogliceryes. Additionally, malonyl-CoA inhibits CPT-1. Mistletoe decreases expression of FAS, ACC, ACS and LPL and decreases SREBP-1c, C/ EBP- $\alpha$, and PPAR- $\gamma$ mRNA expression

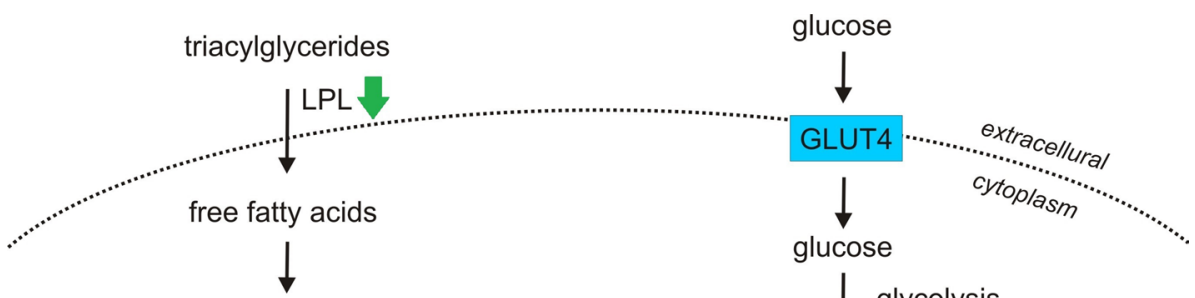

fatty acyl-CoA
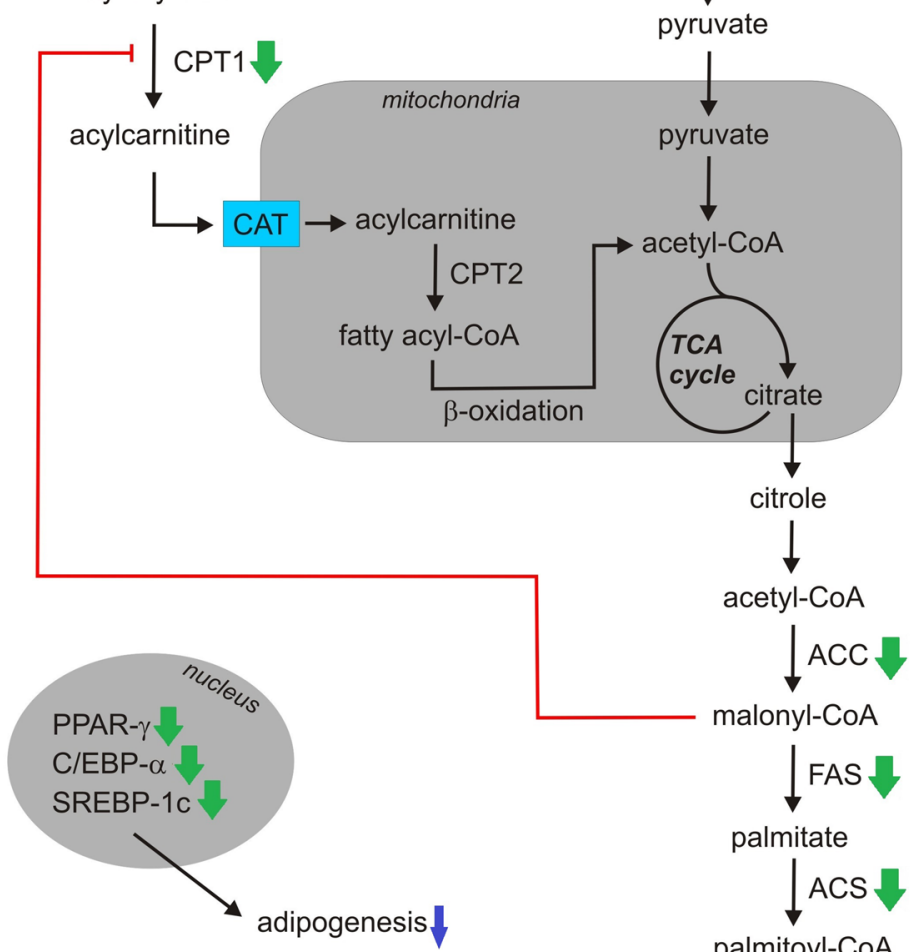

malonyl-CoA

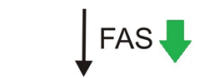

palmitate

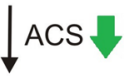

palmitoyl-CoA

fat accumulation $\downarrow \longleftarrow$ triacylglycerides $\longleftarrow$ fatty and neurotransmission across the synapses, promotes synaptic growth and modulates synaptic plasticity (Fig. 6). BDNF also induces hippocampal long-term potentiation, which is important for memory formation. It was found that higher peripheral BDNF levels protect the older adults against Alzheimer's disease ( $\mathrm{Ng}$ et al. 2019).

\section{Antiobesity activity}

Treatment with mistletoe parasitizing oak might influence body and epididymal fat pad weights in vivo and inhibit adipogenic factors in vitro (Table 2). It is known that obesity is related with adipocyte differentiation and the extent of subsequent fat accumulation. Adipogenesis can be induced through the action of enzymes, such as fatty acid synthase (FAS), acyl-CoA synthase (ACC) and acyl-CoA synthetase (ACS). The expressions of these genes are regulated by transcription factors, including peroxisome proliferator-activated receptor $\gamma$ (PPAR- $\gamma$ ), CCAAT/enhancer-binding protein- $\alpha$ $(\mathrm{C} / \mathrm{EBP}-\alpha)$ and sterol regulatory element binding element protein-1c (SREBP-1c), which are known to be crucial activators for adipogenesis and show early changes in gene expression during adipocyte differentiation (Jung et al. 2013). It has been shown that mistletoe treatment significantly decreased SREBP-1c, C/EBP- $\alpha$, and PPAR- $\gamma$ mRNA expression in cultured 3T3-L1 adipocytes and inhibited expression of adipocyte-specific proteins-FAS, ACC, ACS, and LPL (lipoprotein lipase) (Jung et al. 2013). Furthermore, in ovariectomized rats fed a high-fat diet, Korean mistletoe decreased FAS and SREBP-1c expression as well as increased carnitine palmitoyltransferase-1 (CPT-1) expression, a key regulator of fatty acid oxidation (Kim et al. 2015) (Fig. 7). 


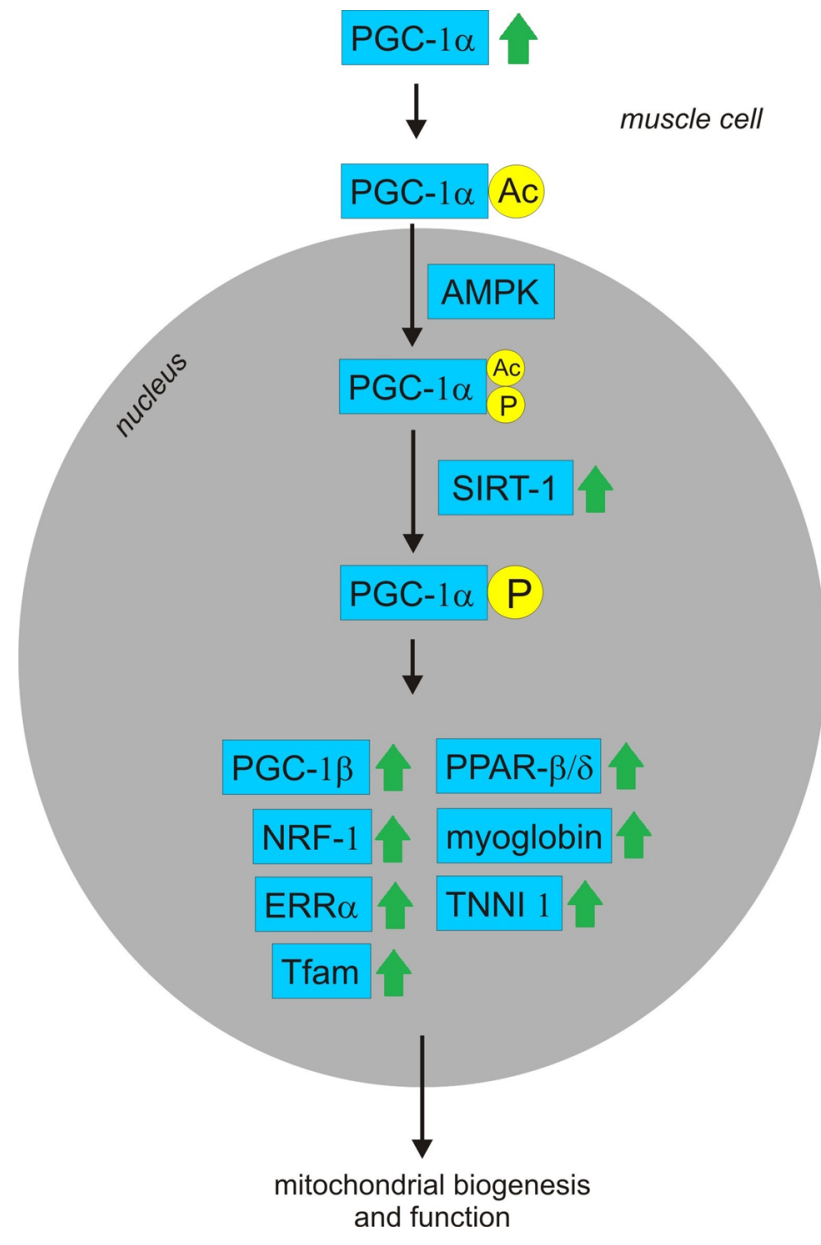

Fig. 8 Probable effect of mistletoe on muscle mitochondrial activity. Two major genes related to mitochondrial biogenesis and function are SIRT-1 and PGC- $1 \alpha$. PGC- $1 \alpha$ translocates into the nucleus where it is phosphorylated by AMPK and deacetylated by SIRT-1. Once phosphorylated and deacetylated, PGC- $1 \alpha$ activity is increased, leading to increased transcription of mitochondrial genes. Korean mistletoe increases the mRNA expression of PGC- $1 \alpha$ and SIRT- 1 and increases the expression of PGC- $1 \alpha$ transcriptional targets such as PGC- $1 \beta$, NRF-1, ERR $\alpha$, Tfam, PPAR $\beta / \delta$, myoglobin and TNNI2

\section{Muscle mitochondrial activity}

It was determined that the administration of an aqueous extract of Korean mistletoe might enhance exercise performance in mice (Jung et al. 2012, 2013; Lee et al. 2014) (Table 2). Jung et al. (2012) showed that an increase in endurance capacity might be mediated by improvement of mitochondrial biogenesis (Fig. 8). Korean mistletoe treatment significantly increased the mitochondrial oxygen consumption rate (OCR) in L6 cells (rat myoblast cell line) as well as increased the mRNA expression of peroxisome proliferator-activated receptor $\gamma$ coactivator (PGC- $1 \alpha$ ) and silent mating type information regulation 2 homolog 1 (SIRT-1), two major genes related to mitochondrial biogenesis and function in $\mathrm{C} 2 \mathrm{C} 12$ cells (mouse myoblast cell line). Korean mistletoe treatment increased the expression of PGC- $1 \alpha$ transcriptional targets, such as PGC- $1 \beta$, NRF-1 (nuclear respiratory factor-1), ERR $\alpha$ (estrogen-related receptor $\alpha$ ), Tfam (mitochondrial transcription factor A), PPAR $\beta / \delta$ (peroxisome proliferator-activated receptor $\beta / \delta$ ), MB (myoglobin) and TNNI2 (troponin I) in C2C12 cells. Additionally, Korean mistletoe decreased levels of plasma lactate and lactate dehydrogenase, parameters of tissue damage and muscle fatigue in exhausted mice (Jung et al. 2012; Lee et al. 2014). Furthermore, exercise training increases the muscular glycogen and plasma free fatty acid (FFA) level, and Korean mistletoe administration increased the plasma FFA level, indicating that Korean mistletoe administration alters the energy resources in muscle (Lee et al. 2014).

\section{Activity against muscle decline}

Supplementation with mistletoe might be effective against age-related decline in muscle mass (Table 2). An in vitro study showed that an aqueous extract of Korean mistletoe caused higher phosphorylation of AKT in $\mathrm{C} 2 \mathrm{C} 12$ cells (mouse myoblast cell line), suggesting that mistletoe has an effect on the regulation of the muscle mass through the activation of the AKT/mTOR (protein kinase B/ mammalian target of rapamycin) signalling pathway (Jeong et al. 2017) (Fig. 9). Furthermore, mistletoe showed increased phosphorylation of FoxO (forkhead box transcription factors of the class $\mathrm{O}$ ) supporting the observation that mistletoe could induce the phosphorylation of AMPK (AMP-activated protein kinase), which is a repressor of FoxO. FoxO is a key molecule inducing muscle atrophy by stimulating the E3 ubiquitin ligases Murf1 and Atrogin-1. In C2C12 cells, as well as in denervated mice, mistletoe decreased gene expression of Atrogin-1. On the contrary, in $\mathrm{C} 2 \mathrm{C} 12$ cells, mistletoe increased mRNA expression of PGC-1 $\alpha$, GLUT-4, and SREBP-1c genes related to the inhibition of muscle atrophy and related to the induction of muscle hypertrophy by regulating the expression of Atrogin-1 and Murf1 (Jeong et al. 2017). Lim et al. (2017) conducted randomized controlled trial confirming that supplementation with Korean mistletoe extract and exercise affects muscle mass and functional capabilities. Supplementation with tablets containing aqueous extracts of Viscum coloratum (Kom.) Nakai was effective for suppressing intracellular pathways related to muscle protein degradation, but stimulated those related to myogenesis. The mRNA expressions levels related to muscle protein degradation (REDD2, TSC2, FoxO1, and atrogin-1) and myogenesis (mTOR, S6K1Rheb, c-Myc, myogenin, and MyoD) as well as the phosphorylation of proteins related to muscle protein degradation (GSK3 $\beta$, GSK3 $\alpha$, TSC 2 , and PTEN) and myogenesis (IGF1R, IR, IRS-1, AKT, mTOR, P70S6K, RPS6 and ERK) were studied. Significant differences were found 
Fig. 9 Probable effect of mistletoe against muscle decline. IGF1 binds to IGF1 receptor leading to activation of PI3K/ AKT/mTOR pathway. Mistletoe leads to higher phosphotylation of AKT resulting in activation of P70S6K, upregulation of myoD and myogenin expression and myogenesis. Mistletoe decreases phosphorylation of PTEN which dephosphorylates $\mathrm{PIP}_{3}$, increasing $\mathrm{PIP}_{2}$ level and resulting in a decreased AKT activity. Furthermore, mistletoe decreases expression of REDD2 which inhibits mTOR pathway. Mistletoe increases phosphorylation of FoxO supporting the observation that mistletoe could induce the phosphorylation of AMPK, which is a repressor of FoxO. AKT also causes phosphorylation and nuclear exclusion of FoxO which is key molecule inducing muscle atrophy by stimulating Murf1 and Atrogin-1. Additionally, FoxO-dependent activation of muscle atrophy is inhibited by PGC- $1 \alpha$

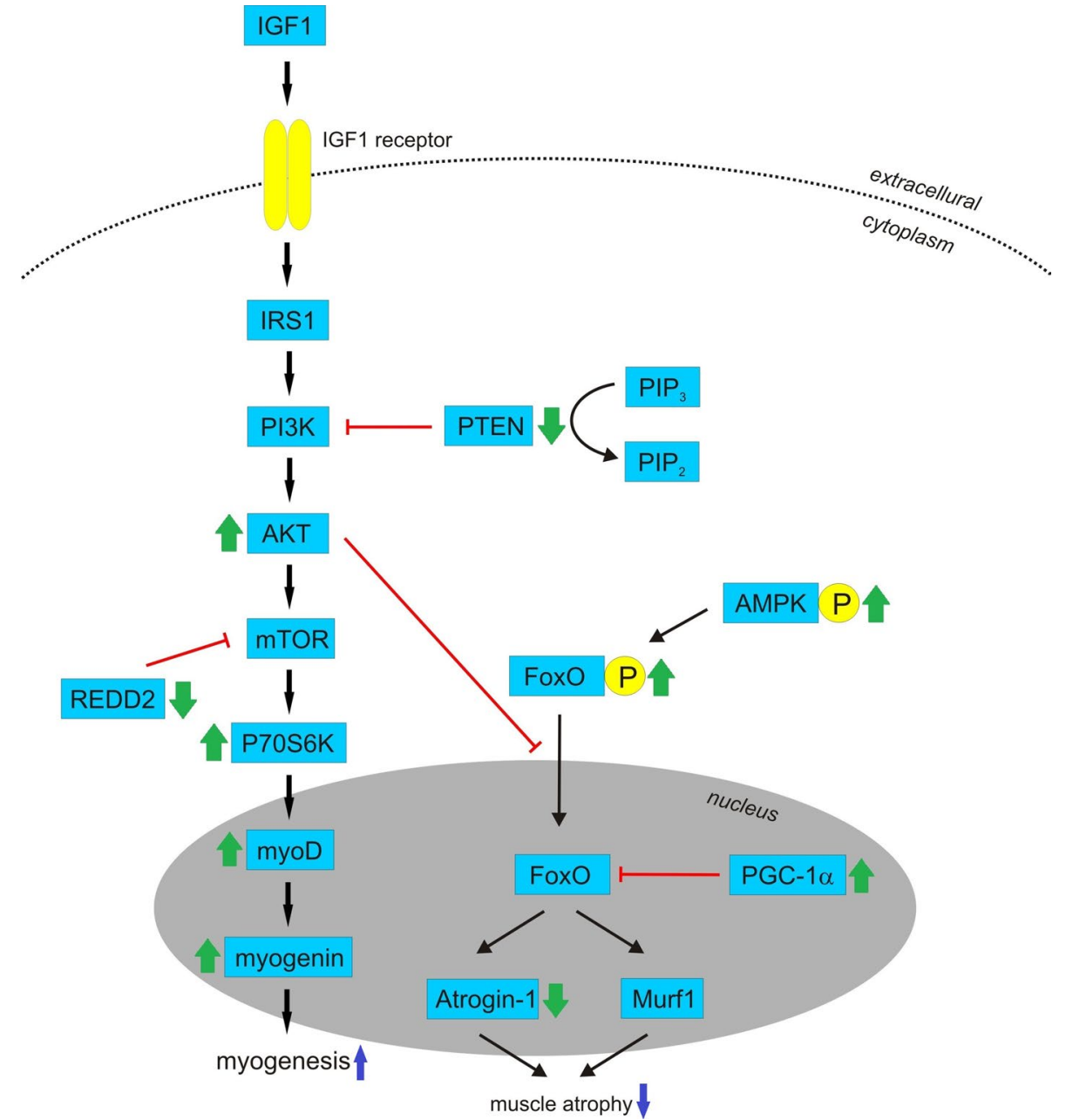

in atrogin-1 mRNA, myogenin mRNA and insulin growth factor 1 receptor phosphorylation. A single administration of mistletoe induced decreases in atrogin-1 gene expression and PTEN (phosphatase and tension homolog) phosphorylation and an increase in myogenin gene expression. A 12-week treatment induced consistent changes in atrogin-1 and myogenin gene expression. Furthermore, the increase of REDD2 gene expression and a decrease of IGF1R phosphorylation shown by the placebo group were retarded in the mistletoe treated group at a 12-week administration. In patients treated with mistletoe, along with an endurance exercise program, the body composition was significantly changed, and knee strength and the dynamic balance ability were improved (Lim et al. 2017).

\section{Antioxidative activity}

Oxidative stress, defined as an imbalance between oxidants and antioxidants in favour of oxidants, leads to many biochemical changes in organisms and is an important contributing factor in several human chronic diseases, such as atherosclerosis and cardiovascular diseases, mutagenesis and cancer, several neurodegenerative disorders, and aging process (Frei 1999). It is suggested that increasing intake of dietary antioxidant may help to maintain a tolerable antioxidant status and help in the disease prevention (Nimse and Pal 2015). Numerous mistletoe extracts and isolated lectin showed radical-scaveging activity and protective effects against oxidative stress induced by free radicals, nitric oxide and superoxide anion $\left(\mathrm{O}_{2}{ }^{-}\right.$) (Sengul et al. 2009; Papuc et al. 2010; Kim et al. 2010, 2016; Kusi et al. 2015). It was studied that the activity of the more polar extracts was higher in different antioxidant mechanism and might result from high level of phenolic and flavonoid compounds (Orhan et al. 2014; Khatun et al. 2016; Pietrzak et al. 2017). Furthermore, antioxidant activity of Viscum species depends on host tree (Vicas and Prokisch, 2009; Vicas et al. 2011; Orhan et al. 2014; Pietrzak et al. 2017) and the time of harvest (ÖnayUçar et al. 2006). 


\section{Nephroprotective and antidiuretic activity}

Helixor M, extract from Viscum album L. growing on apple tree, showed activity against methotrexate (MTX)-induced acute oxidative stress and nephrotoxicity in rats. The mechanism included antioxidant and anti-inflammatory properties, as evident from significant increase in the activities of the antioxidative enzymes, superoxide dismutase (SOD) and glutathione peroxidise (GSH-Px) (Sakalli Çetin et al. 2017). Oleanolic acid isolated from Viscum articulatum Burm. f. showed protective effects on gentamicin-induced renal damage in rats. Oleanolic acid decreased creatinine, albumin and urea levels in the serum and urine. It protected the rat kidneys from histological alterations induced by gentamicin and improved the glomerular filtration rate. The mechanism might be due to antioxidant and diuretic activity (Patil et al. 2010). Diuretic activity was tested for Viscum angulatum B. Heyne ex DC. and Viscum articulatum Burm. f. It was showed that mistletoe had a significant effect on the urine excretion volume. The higher natriuretic activity $\left(\mathrm{Na}^{+} / \mathrm{K}^{+}\right)$ observed suggested a potassium-sparing diuretic effect. Furthermore, the extract showed less influence on the ion quotient $\left(\mathrm{Cl}^{-} / \mathrm{Na}^{+}+\mathrm{K}^{+}\right)$which suggested no inhibition of carbonic anhydrase (Jadhav et al. 2010a, b).

\section{Wound healing}

Viscum articulatum Burm. f., extract showed reduction in wound area in an excision wound model in rats (Table 2). Furthermore, the re-epithelization rate was found to be faster and granuloma breaking strength as well as dry granulation tissue were significantly increased in extract-treated rats (Garg et al. 2012). Kunz et al. (2011) showed in a prospective case series study, wound healing promoting and antitumour effects by the topical treatment of basal cell carcinoma with ointment containing Viscum album L. lipophilic extract. More specifically, an achievement of haemostasis in bleeding tumour wounds, and after a prolonged treatment period, a wound epithelialization with a thin epithelial layer (Kuonen et al. 2013). It is known that, in wound healing processes, many different cell types are involved, including fibroblasts and keratinocytes. As fibroblasts are responsible for initiating angiogenesis, epithelialization, collagen formation and synthesis of extracellular matrix proteins an important step of the proliferative phase of wound healing is the activation of fibroblast migration into the wounded area. An in vitro study showed that Viscum album L. liphophilic extract and its predominant triterpene-oleanolic acid significantly and dose-dependently promoted the migration of $\mathrm{NIH} / 3 \mathrm{~T} 3$ fibroblasts, thereby leading to an enhanced wound closure (Kuonen et al. 2013).

\section{Antiulcer activity}

We found a research regarding the antiulcer activity of mistletoe. Methanolic extract of Viscum articulatum Burm. $\mathrm{f}$ was tested in Pyrolus ligation ulcer and ethanol induced ulcer models in rats. The extract showed significant inhibition of the gastric lesions in both models. Significant reduction in gastric volume, free acidity and ulcer index was observed compared to control. The authors proposed that antiulcerogenic and ulcer healing properties might be due to antisecretory activity of mistletoe (Naganjaneyulu et al. 2011).

\section{Antibacterial activity}

In the need to find new potent antibacterial compounds, the activity of Viscum species was examined in vitro using wide selection of bacterial strains such as Staphylococcus aureus, Staphylococcus epidermidis, Bacillus subtilis, Bacillus atrophaeus, Enterococcus faecium, Escherichia coli, Bordetella bronchisiptica, Salmonella typhi, Pseudomonas aeruginosa, Pseudomonas syringe, Enterobacter cloacae, Proteus vulgaris, Proteus mirabilis, Klebsiella pneumoniae, Klebsiellaaerogenes, Serratiamarcescens, Streptococcus pyogenes, Mycobacterium tuberculosis, Erwinia carotovora, Agrobacterium tumefaciens, Propionibacterium acnes and Xanthomonas campestris (Satish et al. 1999; Deliorman et al. 2001; Erturk et al. 2003; Oguntoye et al. 2008; Sengul et al. 2009; Hussain et al. 2011; Turker et al. 2012; Assaf et al. 2013; Abualhasan et al. 2014; Kusi et al. 2015; Shah et al. 2017). The results obtained are difficult to compare, because researchers used different solvents and various extortion methods to obtain extracts. In addition, some extracts were obtained from the entire plant, and others were obtained from its individual parts such as fruits, leaves or steams (Hussain et al. 2011; Shah et al. 2017). Mistletoe was also obtained from various types of host trees (Deliorman et al. 2001; Turker et al. 2012). Those interested are invited to read the quoted articles. We found only one in vivo study carried out on rats infected by Staphylococcus aureus + Bacillus cereus, Escherichia coli + Pseudomonas aeruginosa, Staphylococcus aureus + Pseudomonas aeruginosa and Escherichia coli. Haematological and histopathological studies, after 7 days of treatment with methanolic extract of Viscum album L. parasitizing cocoa trees, exhibited its therapeutic effect (Yusuf et al. 2013) (Table 2). Researchers have noticed that antibacterial activity of the extracts was more effective against Gram-negative bacteria than against Gram-positive bacteria (Erturk et al. 2003; Hussain et al. 2011) and postulated that the antibacterial effects were through anti-biofilm activity (Kenar et al. 2016). 


\section{Antifungal activity}

Antifungal activity was most often tested on Candida species, which are important pathogens causing substantial morbidity and mortality in hospitalized critically ill patients (Jahagirdar et al. 2018). Nacsa-Farkas et al. (2014) tested activity of ethanolic extract of Viscum album L. against twelve Candida species, of which the most sensitive was Candida inconspicua (MIC $5.65 \mathrm{mg} / \mathrm{mL}$ ). A methanolic extract of Viscum cruciatum Sieber ex Boiss. leaves exhibited activity against Candida albicans with MIC $1.25 \mathrm{mg} /$ $\mathrm{mL}$ (Assaf et al. 2013). Furthermore, an n-hexane extract of Viscum album subsp. abietis (Wiesb.) Abrom. and its two fractions after flash column preparation were tested against Candida albicans. The first fraction was active at a concentration of $1 \mathrm{mg} / \mathrm{mL}$ (ZI (zone inhibition) $11 \mathrm{~mm}$ ), whereas the second fraction showed activity at a concentration of $10 \mathrm{mg} / \mathrm{mL}$ (ZI $10 \mathrm{~mm}$ ) (Erturk et al. 2003). Shah et al. (2017) compared the activity of different parts of Viscum album L. against Candida albicans. For steam distillations, the most active was the butanol extract, which showed 25.66 and $30.00 \mathrm{~mm}$ ZI at 1 and $2 \mathrm{mg} /$ disc, respectively. For leaves, the methanol extract was the most active, reducing the growth of Candida albicans as 25.00 and $30.00 \mathrm{~mm} \mathrm{ZI}$ at 1 and $2 \mathrm{mg} / \mathrm{disc}$, respectively. For fruits, the most potent was the n-hexane extract, which reduced the growth of $\mathrm{Can}$ dida albicans by $22.00 \mathrm{~mm} \mathrm{ZI} \mathrm{at} \mathrm{both} \mathrm{concentrations} \mathrm{(} 1$ and $2 \mathrm{mg} / \mathrm{disc}$ ). On the other hand, methanolic, dichloromethane and aqueous extracts of Viscum capense L. f. stems had no effect on the growth of Candida albicans (Amabeoku et al. 1998). Furthermore, Hussain et al. (2011) studied various extracts of Viscum album L. leaves and twigs and found that they were not effective against Saccharomyces cerevisiae and Aspergillus flavus. Methanolic extracts of leaves of Viscum album L. growing on cocoa and cola trees inhibited the growth of Fusarium oxysporium, Penicillium oxalium and Microsporum canis, but the highest activity was obtained against Aspergillus niger (ZI 10.66 $\pm 1.45 \mathrm{~mm}$ ) (Yusuf et al. 2014). The petroleum ether extract of Viscum album L. leaves was found to be more effective against Aspergillus niger, Fusarium oxysporium, Botryodiplodia theobromae and Geotrichum candidum than methanolic extract. The highest activity was exhibited by the petroleum ether extract against Botryodiplodia theobromae with ZI of $15.85 \mathrm{~mm}$ (Akalazu et al. 2016). It was proposed that two compounds, caprylamide and linolelaidic acid methyl ester, might be the major antifungal compounds in the leaves of mistletoe (***Akalazu et al. 2016). Other compounds active against fungi might be viscotoxines. Viscotoxin A3 and viscotoxin $\mathrm{B}$, at a concentration of $10 \mu \mathrm{M}$, blocked the germination of spores, and at lower concentration than $10 \mu \mathrm{M}$, inhibited the mycelial growth of Fusarium solani, Sclerotinia sclerotiorum and Phytophthora infestans. It was postulated that viscotoxin A3 might bind to membranes and form ion channels, leading to destabilization and disruption of the plasma membrane (Giudici et al. 2003, 2004, 2006).

\section{Antiviral activity}

So far, the antiviral activity of mistletoe has not been extensively investigated. The aqueous extract of leaves of Viscum album L. growing on lime trees was found to be effective against human parainfluenza virus type 2 (HPIV2) growth in Vero cells. The extract, at a dose of $1 \mu \mathrm{g} / \mathrm{mL}$, inhibited HPIV-2 replication and suppressed virus production by $99.7 \%$ (ED50 $0.53 \mu \mathrm{g} / \mathrm{mL}$ ) with no toxic effect on host cells (Karagöz et al. 2003). The methanolic extract of Viscum album L. leaves was active against measles virus growth in Vero cells at $0.063 \mu \mathrm{g} / \mu \mathrm{L}\left(\mathrm{IC}_{50} 0.031 \mu \mathrm{g} / \mu \mathrm{L}\right)$ and $0.031 \mu \mathrm{g} / \mu \mathrm{L}\left(\mathrm{IC}_{50} 0.039 \mu \mathrm{g} / \mu \mathrm{L}\right)$. On the other hand, the polio, yellow fever and simplex virus-1 (HSV-1) viruses were resistant to the same extract (Obi and Shenge 2018). Due to the strong impact of mistletoe on the immune system, it was proposed that it might be useful as a complementary treatment of patients with human immunodeficiency virus (HIV). Studies to confirm the induction of immunomodulation and possibility of the inhibition of the progression of HIV disease are needed (Gorter et al. 1996, 1999; Stoss and Gorter 1998; Stoss et al. 1999). An in vitro study revealed that a phenolic glycoside, homoeriodictyol7-O- $\beta$-D-glucopyranoside-4'- $O-\beta$-D-apiofuranoside, isolated from Viscum articulatum Burm. f. growing on Fagaceae: Lithocarpus variolosus (Franch.) Chunex showed weak antiHIV-1 activity with $\mathrm{CC}_{50}>200 \mu \mathrm{g} / \mathrm{mL}$ and $\mathrm{EC}_{50}=18.09 \mu \mathrm{g} /$ $\mathrm{mL}$. This compound exerted its weak protection of HIV1UB-induced MT-4 host cell lytic effects with a TI > 11.06 (Li et al. 2008).

\section{Conclusion}

Traditionally mistletoe has been used in a treatment of many diseases. To date, the anticancer and immunomodulatory activities of Viscum species were the most studied. In Europe, mainly in German-speaking countries, this resulted in the launch of extracts for subcutaneous or intravenous administration to improve the quality of life and survival of cancer patients. Lately, an extensive number of in vitro and in vivo studies have been conducted to investigate the other pharmaceutical activities of mistletoe. The results of these studies (Table2) showed that mistletoe might be a potential source of new drugs and complementary therapies to treat hypertension, diabetes, liver diseases, epilepsy and Alzheimer's disease. Furthermore, it might be used to improve endurance and muscle strength, enhance wound healing and 
as antibacterial and antifungal agent. Such a wide variety of pharmaceutical properties is due to the content of many biologically active compounds from various chemical groups. The chemical composition of mistletoe depends on part of the plant (stem, leaves, fruits) and host species as well as the place and time of harvest. To date, the active compounds responsible for the individual pharmacological activities of mistletoe have not been identified. Further studies on fractionation and isolation of main active compounds and the development of methods of standardization of the extracts are required. Such studies should be conducted for extracts prepared from mistletoe parasitizing various host trees, different harvesting periods and different parts of the plant. In the next step of research, the mechanisms of action need to be tested, not only for individual isolated active compounds, but also for the whole extracts. This is because the therapeutic effect of mistletoe might be a result of the synergistic interactions of various secondary metabolites. Those interactions might include both low-molecular weight compounds (such as phenolic acids, flavonoids and fatty acids) and high-molecular weight substances (such as viscotoxines and lectins). Because of the diverse synergistic interactions, the mechanism of action of mistletoe might include many signalling pathways. Mistletoe might regulate either the same or different targets in various pathways, while acting on membrane receptors, enzymes, ion channels, transporter proteins and transcriptional targets. In this review, we summarized the existing studies on pharmacological activities of Viscum species and proposed possible mechanisms of action. Still, this is a new field for scientific research, and further studies on compound isolation and identification, synergistic interactions, metabolism, mechanisms of action and toxicity are required. We believe that due to this research, mistletoe will become a source of new complementary therapies supporting the treatment of many diseases.

Acknowledgements The authors received no financial support for publication of this article.

\section{Compliance with ethical standards}

Conflict of interest The authors declare no conflicts of interest.

Open Access This article is licensed under a Creative Commons Attribution 4.0 International License, which permits use, sharing, adaptation, distribution and reproduction in any medium or format, as long as you give appropriate credit to the original author(s) and the source, provide a link to the Creative Commons licence, and indicate if changes were made. The images or other third party material in this article are included in the article's Creative Commons licence, unless indicated otherwise in a credit line to the material. If material is not included in the article's Creative Commons licence and your intended use is not permitted by statutory regulation or exceeds the permitted use, you will need to obtain permission directly from the copyright holder. To view a copy of this licence, visit http://creativecommons.org/licenses/by/4.0/.

\section{References}

Abdel-Salam OM, Sleem AA, Shaffie NM (2010) Effect of Viscum album on acute hepatic damage caused by carbon tetrachloride in rats. Turk J Med Sci 40:421-426. https://doi.org/10.3906/ sag-0803-12

Abdel-Sattar EA, Elberry AA, Harraz FM, Ghareib SA, Nagy AA, Gabr SA (2011) Antihyperglycemic and hypolipidaemic effects of the methanolic extract of Saudi mistletoe (Viscum schimperi Engl.). J Adv Res 2:171-177. https://doi.org/10.1016/J. JARE.2011.01.006

Abualhasan M, Jaradat N, Abu-Hasan N, Almasri M, Taha AA, Rabbaa A, Natsheh N, Shalalfeh S, Najib M (2014) Bioactivity of Viscum album extracts from olive and almond host plants in Palestine. Pharmacogn J 6:117-123. https://doi.org/10.5530/pj.2014.2.7

Adaramoye O, Amanlou M, Habibi-Rezaei M, Pasalar P, Ali M-M (2012) Methanolic extract of African mistletoe (Viscum album) improves carbohydrate metabolism and hyperlipidemia in streptozotocin-induced diabetic rats. Asian Pac J Trop Med 5:427433. https://doi.org/10.1016/S1995-7645(12)60073-X

Ademola O, Edem E, Olufunke D, Oladunni K (2016) Cognitiveenhancing and neurotherapeutic prospects of Viscum album in experimental model of Alzheimer's disease. African J Cell Pathol 7:11-16

Akalazu JN, Ohazurike NC, Onuoha CI (2016) Antifungal activity of Viscum album (African mistletoe) leaf extract on Dioscorea rotundata (poir) (white yam) tuber rot disease. Int J Adv Sci Eng Technol 4:189-191. https://doi.org/10.13140/RG.2.2.29874 .66248

Amabeoku GJ, Leng MJ, Syce JA (1998) Antimicrobial and anticonvulsant activities of Viscum capense. J Ethnopharmacol 61:237241. https://doi.org/10.1016/s0378-8741(98)00054-3

Assaf AM, Haddadin RN, Aldouri NA, Alabbassi R, Mashallah S, Mohammed M, Bustanji Y (2013) Anti-cancer, anti-inflammatory and anti-microbial activities of plant extracts used against hematological tumors in traditional medicine of Jordan. J Ethnopharmacol 145:728-736. https://doi.org/10.1016/j. jep.2012.11.039

Bachhav SS, Patil SD, Bhutada MS, Surana SJ (2011) Oleanolic acid prevents glucocorticoid-induced hypertension in rats. Phyther Res 25:1435-1439. https://doi.org/10.1002/ptr.3431

Bachhav SS, Bhutada MS, Patil SD, Baser B, Chaudhari KB (2012) Effect of Viscum articulatum Burm. (Loranthaceae) in N $\omega$-nitroL-arginine methyl ester induced hypertension and renal dysfunction. J Ethnopharmacol 142:467-473. https://doi.org/10.1016/j. jep.2012.05.021

Bachhav SS, Bhutada MS, Patil SP, Sharma KS, Patil SD (2015) Oleanolic acid prevents increase in blood pressure and nephrotoxicity in nitric oxide dependent type of hypertension in rats. Pharmacognosy Res 7:385-392. https://doi.org/10.4103/09748490.159575

Bar-Sela G (2011) White-Berry Mistletoe (Viscum album L.) as complementary treatment in cancer: does it help? Eur J Integr Med 3:e55-e62. https://doi.org/10.1016/J.EUJIM.2011.03.002

Bar-Sela G, Wollner M, Hammer L, Agbarya A, Dudnik E, Haim N (2013) Mistletoe as complementary treatment in patients with advanced non-small-cell lung cancer treated with carboplatinbased combinations: a randomised phase II study. Eur J Cancer 49:1058-1064. https://doi.org/10.1016/J.EJCA.2012.11.007

Braedel-Ruoff S (2010) Immunomodulatory effects of Viscum album Extracts on natural killer cells: review of clinical trials. Res Complement Med 17:63-73. https://doi.org/10.1159/000288702

Brandenberger M, Simões-Wüst AP, Rostock M, Rist L, Saller R (2012) An exploratory study on the quality of life and individual 
coping of cancer patients during mistletoe therapy. Integr Cancer Ther 11:90-100. https://doi.org/10.1177/1534735411413267

Bussing A (2000) Mistletoe. The genus Viscum. Hardwood Academic Publishers, Amsterdam. https://doi.org/10.1021/np000751e

Ćebović T, Spasić S, Popović M (2008) Cytotoxic effects of the Viscum album L. extract on Ehrlich tumour cells in vivo. Phyther Res 22:1097-1103. https://doi.org/10.1002/ptr.2464

Choi JH, Lyu SY, Lee HJ, Jung J, Park WB, Kim GJ (2012) Korean mistletoe lectin regulates self-renewal of placenta-derived mesenchymal stem cells via autophagic mechanisms. Cell Prolif 45:420-429. https://doi.org/10.1111/j.1365-2184.2012.00839.x

Choi SH, Lyu SY, Park WB (2004) Mistletoe lectin induces apoptosis and telomerase inhibition in human A253 cancer cells through dephosphorylation of Akt. Arch Pharm Res 27:68-76. https:// doi.org/10.1007/BF02980049

Chu W, Qiao G, Bai Y, Pan Z, Li G, Piao X, Wu L, Lu Y, Yang B (2008) Flavonoids from Chinese Viscum coloratum produce cytoprotective effects against ischemic myocardial injuries: inhibitory effect of flavonoids on PAF-Induced Ca2+ overload. Phyther Res 22:134-137. https://doi.org/10.1002/ptr.2267

Committee on Herbal Medicinal Products (2012) Assessment report on Viscum album L., herba. Committee on Herbal Medicinal Product, London

Dela Cruz JF, Kim YS, Lumbera WM, Hwang SG (2015) Viscum album var hot water extract mediates anti-cancer effects through G1 phase cell cycle arrest in SK-Hep1 human hepatocarcinoma cells. Asian Pac J Cancer Prev 16:6417-6421. https://doi. org/10.7314/APJCP.2015.16.15.6417

Delebinski CI, Twardziok M, Kleinsimon S, Hoff F, Mulsow K, Rolff J, Jager S, Eggert A, Seifert G (2015) A natural combination extract of Viscum album L. containing both triterpene acids and lectins is highly effective against AML in vivo. PLoS ONE 10:e0133892. https://doi.org/10.1371/journal.pone.0133892

Deliorman D, Ergun F, Sener B, Palittapongarnpim P (2001) Evaluation of antimycobacterial activity of Viscum album subspecies. Pharm Biol 39:381-383. https://doi.org/10.1076/phbi.39.5.381.5900

Diniz TC, Silva JC, de Lima-Saraiva SR, Ribeiro FP, de Freitas RM, Quintans-Júnior LJ, Quintans Jde S, Mendes RL, Almeida JR (2015) The role of flavonoids on oxidative stress in epilepsy. Oxid Med Cell Longev 2015:9. https://doi.org/10.1155/2015/171756

Eggenschwiler J, von Balthazar L, Stritt B, Pruntsch D, Ramos M, Urech K, Rist L, Simoes-Wust P, Viviani A (2007) Mistletoe lectin is not the only cytotoxic component in fermented preparations of Viscum album from white fir (Abies pectinata). BMC Complement Altern Med 7:1-7. https://doi.org/10.1186/1472-6882-7-14

Ekpenyong EE, Ayodele OA, Linus E (2016) Viscum album enhanced blood serum brain-derived neurotrophic factor (BDNF) level in experimental model of Alzheimer's disease. World J Pharm Pharm Sci 5:157-171

Elluru SR, Duong Van Huyen JP, Delignat S, Prost F, Heudes D, Kazatchkine MD, Friboulet A, Kaveri SV (2009) Antiangiogenic properties of Viscum album extracts are associated with endothelial cytotoxicity. Anticancer Res 29:2945-2950

Elluru SR, van Huyen JPD, Delignat S, Kazatchkine MD, Friboulet A, Kaveri SV, Bayry J (2008) Induction of maturation and activation of human dendritic cells: a mechanism underlying the beneficial effect of Viscum album as complimentary therapy in cancer. BMC Cancer 8:161. https://doi.org/10.1186/1471-2407-8-161

Eno AE, Ofem OE, Nku CO, Ani EJ, Itam EH (2008) Stimulation of insulin secretion by Viscum album (mistletoe) leaf extract in streptozotocin-induced diabetic rats. Afr J Med Med Sci 37:141-147

Ernst E, Schmidt K, Steuer-Vogt MK (2003) Mistletoe for cancer? A systematic review of randomised clinical trials. Int J Cancer 107:262-267. https://doi.org/10.1002/ijc.11386
Erturk Ö, Kati H, Yayli N, Demirbag Z (2003) Antimicrobial activity of Viscum album L. subsp. abietis (Wiesb). Turk J Biol 27:255-258

Fan J, Wu M, Wang J, Ren D, Zhao J, Yang G (2019) 1,7-Bis(4hydroxyphenyl)-1,4-heptadien-3-one induces lung cancer cell apoptosis via the PI3K/Akt and ERK1/2 pathways. J Cell Physiol 234:6336-6349. https://doi.org/10.1002/jcp.27364

Felenda JE, Turek C, Stintzing FC (2019) Antiproliferative potential from aqueous Viscum album L. preparations and their main constituents in comparison with ricin and purothionin on human cancer cells. J Ethnopharmacol 236:100-107. https://doi. org/10.1016/j.jep.2019.02.047

Frei B (1999) Molecular and biological mechanisms of antioxidant action. FASEB J 13:963-964. https://doi.org/10.1096/faseb j.13.9.963

Freuding M, Keinki C, Micke O, Buentzel J, Huebner J (2019) Mistletoe in oncological treatment: a systematic review: part 1: survival and safety. J Cancer Res Clin Oncol 145:695-707. https://doi. org/10.1007/s00432-018-02837-4

Gardin NE (2009) Immunological response to mistletoe (Viscum album L.) in cancer patients: a four-case series. Phyther Res 23:407411. https://doi.org/10.1002/ptr.2643

Garg S, Patil UK, Shrivastava TP (2012) Wound healing potential of Viscum Articulum Brm., an ethnomedical plant of Sikkim on rat. Int J Res Phytochem Pharmacol 2:138-142. https://doi. org/10.1186/s13002-017-0148-9

Geetha KM, Bhaskara Gopal PVVS, Murugan V (2010) Antiepileptic activity of aerial parts of Viscum articulatum (Viscaceae) in rats. J Pharm Res 3:2886-2887

Geetha KM, Murugan V, Pavan Kumar P, Wilson B (2018) Antiepileptic activity of Viscum articulatum Burm and its isolated bioactive compound in experimentally induced convulsions in rats and mice. Eur J Biomed Pharm Sci 5:311-318

Giudici AM, Regente MC, Villalain J, Pfuller K, Pfuller U, De La Canal L (2004) Mistletoe viscotoxins induce membrane permeabilization and spore death in phytopathogenic fungi. Physiol Plant 121:2-7. https://doi.org/10.1111/j.0031-9317.2004.00259 $\mathrm{X}$

Giudici M, Poveda JA, Molina ML, De La Canal L, Gonzales-Ros JM, Pfuller K, Pfuller U, Villalain J (2006) Antifungal effects and mechanism of action of viscotoxin A3. FEBS J 273:72-83. https ://doi.org/10.1111/j.1742-4658.2005.05042.x

Giudici M, Pascual R, De La Canal L, Pfuller K, Pfuller U, Villalain J (2003) Interaction of viscotoxins A 3 and B with membrane model systems: implications to their mechanism of action. Biophys J 85:971-981. https://doi.org/10.1016/S0006 $-3495(03) 74536-6$

Gorter RW, Stein J, Stoss M, Linder M (1996) Prospektive, longitudinale, Dosis-eskalierende, randomisierte Phase-L/Ll-Studie mit Iscador $^{\circledR}$ QuFrF und Iscador ${ }^{\circledR}$ Qu Spezial mit HIV-Positiven, Krebspatienten und gesunden, nichtrauchenden Probanden. Complement Med Res 3:169-175. https://doi.org/10.1159/000210221

Gorter RW, van Wely M, Reif M, Stoss M (1999) Tolerability of an extract of European mistletoe among immunocompromised and healthy individuals. Altern Ther Health Med 5(37-44):47-48

Gray AM, Flatt PR (1999) Insulin-secreting activity of the traditional antidiabetic plant Viscum album (mistletoe). J Endocrinol 160:409-414. https://doi.org/10.1677/joe.0.1600409

Gupta G, Kazmi I, Afzal M, Rahman M, Saleem S, Ashraf S, Khusroo MJ, Nazeer K, Ahmed S, Mujeeb M, Ahmed Z, Anwar F (2012) Sedative, antiepileptic and antipsychotic effects of Viscum album L. (Loranthaceae) in mice and rats. J Ethnopharmacol 141:810 816. https://doi.org/10.1016/j.jep.2012.03.013

Hajto T (1986) Immunomodulatory effects of Iscador: a Viscum album preparation. Oncology 43:51-65. https://doi.org/10.1159/00022 6420 
Hajto T, Hostanska K, Frei K, Rordorf C, Gabius HJ (1990) Increased secretion of tumor necrosis factors alpha, interleukin 1 , and interleukin 6 by human mononuclear cells exposed to beta-galactoside-specific lectin from clinically applied mistletoe extract. Cancer Res 50:3322-3326

Han SY, Hong CE, Kim HG, Lyu SY (2015) Anti-cancer effects of enteric-coated polymers containing mistletoe lectin in murine melanoma cells in vitro and in vivo. Mol Cell Biochem 408:7387. https://doi.org/10.1007/s11010-015-2484-1

Hegde P, Maddur MS, Friboulet A, Bayry J, Kaveri SV (2011) Viscum album exerts anti-inflammatory effect by selectively inhibiting cytokine-induced expression of cyclooxygenase-2. PLoS ONE 6:e26312. https://doi.org/10.1371/journal.pone.0026312

Heiny BM, Beuth J (1994) Mistletoe extract standardized for the galactoside-specific lectin (ML-1) induces beta-endorphin release and immunopotentiation in breast cancer patients. Anticancer Res 14:1339-1342

Heiny BM, Albrecht V, Beuth J (1998) Correlation of immune cell activities and beta-endorphin release in breast carcinoma patients treated with galactose-specific lectin standardized mistletoe extract. Anticancer Res 18:583-586

Hmadcha A, Martin-Montalvo A, Gauthier BR, Soria B, Capilla-Gonzalez V (2020) Therapeutic potential of mesenchymal stem cells for cancer therapy. Front Bioeng Biotechnol 8:43. https://doi. org/10.3389/fbioe.2020.00043

Hong CE, Park AK, Lyu SY (2014) Synergistic anticancer effects of lectin and doxorubicin in breast cancer cells. Mol Cell Biochem 394:225-235. https://doi.org/10.1007/s11010-014-2099-y

Huber R, Lüdtke H, Wieber J, Beckmann C (2011) Safety and effects of two mistletoe preparations on production of Interleukin- 6 and other immune parameters-a placebo controlled clinical trial in healthy subjects. BMC Complement Altern Med 11:116. https ://doi.org/10.1186/1472-6882-11-116

Huber R, Lüdtke R, Klassen M, Muller-Buscher G, Wolff-Vorbeck G, Scheer R (2001) Effects of a mistletoe preparation with defined lectin content on chronic hepatitis $\mathrm{C}$ : an individually controlled cohort study. Eur J Med Res 6:399-405

Huber R, Rostock M, Goedl R, Ludtke R, Urech K, Buck S, Klein R (2005) Mistletoe treatment induces GM-CSF- and IL-5 production by PBMC and increases blood granulocyte- and eosinophil counts: a placebo controlled randomized study in healthy subjects. Eur J Med Res 10:411-418

Hussain MA, Khan MQ, Hussain N, Habib T (2011) Antibacterial and antifungal potential of leaves and twigs of Viscum album L. J Med Plants Res 5:5545-5549

Ibegbulem CO, Chikezie PC (2013) Hypoglycemic properties of ethanolic extracts of Gongronema latifolium, Aloe perryi, Viscum album and Allium sativum administered to alloxan-induced diabetic albino rats (Rattus norvegicus). Pharmacogn Commun 3:12-16. https://doi.org/10.5530/pc.2013.2.4

Jadhav N, Patil CR, Chaudhari KB, Wagh JP, Surana SJ, Jadhav RB (2010a) Diuretic and natriuretic activity of two mistletoe species in rats. Pharmacognosy Res 2:50-57. https://doi. org/10.4103/0974-8490.60576

Jadhav RB, Bhatnagar SP, Surana SJ (2010b) Diuretic activity of squamate mistletoe, Viscum angulatum. Pharm Biol 48:417-421. https://doi.org/10.3109/13880200903150427

Jäger AK, Saaby L (2011) Flavonoids and the CNS. Molecules 16:1471-1485. https://doi.org/10.3390/molecules16021471

Jahagirdar V, Davane M, Aradye S, Nagoba B (2018) Candida species as potential nosocomial pathogens-a review. Eur J Gen Med 15:71-75. https://doi.org/10.29333/ejgm/82346

Jang JY, Kim SY, Song KS, Seong YH (2015) Korean mistletoe (Viscum album var. coloratum) inhibits amyloid beta protein (25-35)-induced cultured neuronal cell damage and memory impairment. Nat Prod Sci 21:134-140
Jeong J, Park CH, Kim I, Kim YH, Yoon JM, Kim KS, Kim JB (2017) Korean mistletoe (Viscum album coloratum) extract regulates gene expression related to muscle atrophy and muscle hypertrophy. BMC Complement Altern Med 17:68. https://doi. org/10.1186/s12906-017-1575-9

Jiang Y, Wang C, Li YY, Wang XC, An JD, Wang YJ, Wang XJ (2014) Mistletoe alkaloid fractions alleviates carbon tetrachloride-induced liver fibrosis through inhibition of hepatic stellate cell activation via TGF- $\beta /$ Smad interference. J Ethnopharmacol 158:230-238. https://doi.org/10.1016/J.JEP.2014.10.028

Jung HY, Kim YH, Kim IB, Jeong JS, Lee JH, Do MS, Jung SP, Kim KS, Kim KT, Kim JB (2013) The Korean mistletoe (Viscum album coloratum) extract has an antiobesity effect and protects against hepatic steatosis in mice with high-fat diet-induced obesity. Evid Based Complement Altern Med 2013:1-9. https://doi. org/10.1155/2013/168207

Jung HY, Lee AN, Song TJ, An HS, Kim YH, Kim KD, Kim IB, Kim KS, Han BS, Kim CH, Kim KS, Kim JB (2012) Korean mistletoe (Viscum album coloratum) extract improves endurance capacity in mice by stimulating mitochondrial activity. J Med Food 15:621-628. https://doi.org/10.1089/jmf.2010.1469

Karagöz A, Kesici S, Vural A, Usta M, Tezcan B, Semerci T, Teker E (2016) Cardioprotective effects of Viscum album L. ssp. album (Loranthaceae) on isoproterenol-induced heart failure via regulation of the nitric oxide pathway in rats. Anatol J Cardiol 16:923930. https://doi.org/10.14744/AnatolJCardiol.2016.6780

Karagöz A, Önay E, Arda N, Kuru A (2003) Antiviral potency of mistletoe (Viscum album ssp. album) extracts against human parainfluenza virus type 2 in Vero cells. Phyther Res 17:560-562. https ://doi.org/10.1002/ptr.1163

Kenar N, Erdonmez D, Turkmen KE (2016) Anti-quorum sensing and anti-biofilm activity of Viscum album L. on different pathogenic bacteria. J Biotechnol 1000:1000. https://doi.org/10.1016/J. JBIOTEC.2016.05.138

Khan T, Ali S, Qayyum R, Hussain I, Wahid F, Shah AJ (2016) Intestinal and vascular smooth muscle relaxant effect of Viscum album explains its medicinal use in hyperactive gut disorders and hypertension. BMC Complement Aternative Med 16:251. https://doi. org/10.1186/s12906-016-1229-3

Khatun A, Rahman M, Rahman MM, Hossain H, Jahan IA, Nesa L (2016) Antioxidant, antinociceptive and CNS activities of Viscum orientale and high sensitive quantification of bioactive polyphenols by UPLC. Front Pharmacol 7:176. https://doi. org/10.3389/fphar.2016.00176

Kienle GS, Grugel R, Kiene H (2011) Safety of higher dosages of Viscum album L. in animals and humans-systematic review of immune changes and safety parameters. BMC Complement Altern Med. https://doi.org/10.1186/1472-6882-11-72

Kienle GS, Kiene H (2010) Influence of Viscum album L (European Mistletoe) extracts on quality of life in cancer patients: a systematic review of controlled clinical studies. Integr Cancer Ther 9:142-157. https://doi.org/10.1177/1534735410369673

Kienle GS, Mussler M, Fuchs D, Kiene H (2016) Intravenous mistletoe treatment in integrative cancer care: a qualitative study exploring the procedures, concepts, and observations of expert doctors. Evid Based Complement Altern Med 2016:1-16. https://doi. org/10.1155/2016/4628287

Kim BK, Choi MJ, Park KY, Cho EJ (2010) Protective effects of Korean mistletoe lectin on radical-induced oxidative stress. Biol Pharm Bull 33:1152-1158. https://doi.org/10.1248/bpb.33.1152

Kim GD, Choi JH, Lim SM, Jun JH, Moon JW, Kim GJ (2019) Alterations in IL-6/STAT3 signaling by Korean mistletoe lectin regulate the self-renewal activity of placenta-derived mesenchymal stem cells. Nutrients 11:2604. https://doi.org/10.3390/nu111 12604 
Kim JJ, Hwang YH, Kang K-Y, Kim I, Kim JB, Park JH, Yoo YC, Yee ST (2014a) Enhanced dendritic cell maturation by the B-chain of Korean mistletoe lectin (KML-B), a novel TLR4 agonist. Int Immunopharmacol 21:309-319. https://doi.org/10.1016/J.INTIM P.2014.05.010

Kim KC, Yook JH, Eisenbraun J, Kim BS, Huber R (2012) Quality of life, immunomodulation and safety of adjuvant mistletoe treatment in patients with gastric carcinoma-a randomized, controlled pilot study. BMC Complement Altern Med 12:172. https ://doi.org/10.1186/1472-6882-12-172

Kim KW, Yang SH, Kim JB (2014b) Protein fractions from Korean mistletoe (Viscum album coloratum) extract induce insulin secretion from pancreatic beta cells. Evid Based Complement Altern Med 703624:8. https://doi.org/10.1155/2014/703624

Kim MJ, Park JH, Kwon DY, Yang HJ, Kim DS, Kang S, Shin BK, Moon NR, Song BS, Kim JH, Park S (2015) The supplementation of Korean mistletoe water extracts reduces hot flushes, dyslipidemia, hepatic steatosis, and muscle loss in ovariectomized rats. Exp Biol Med 240:477-487. https://doi.org/10.1177/15353 70214551693

Kim SY, Yang EJ, Son YK, Yeo JH, Song KS (2016) Enhanced antioxidative effect of fermented Korean mistletoe is originated from an increase in the contents of caffeic acid and lyoniresinol. Food Funct 7:2270-2277. https://doi.org/10.1039/c6fo00138f

Kim S, Kim KC, Lee C (2017) Mistletoe (Viscum album) extract targets Axl to suppress cell proliferation and overcome cisplatin- and erlotinib-resistance in non-small cell lung cancer cells. Phytomedicine 36:183-193. https://doi.org/10.1016/J.PHYME D.2017.09.017

Kim Y, Kim I, Park CH, Kim JB (2018) Korean mistletoe lectin enhances natural killer cell cytotoxicity via upregulation of perforin expression. Asian Pac J Allergy Immunol 36:175-183. https ://doi.org/10.12932/AP-030417-0067

Kleinsimon S, Kauczor G, Jaeger S, Eggert A, Seifert G, Delebinski C (2017) ViscumTT induces apoptosis and alters IAP expression in osteosarcoma in vitro and has synergistic action when combined with different chemotherapeutic drugs. BMC Complement Altern Med 17:26. https://doi.org/10.1186/s12906-016-1545-7

Kleinsimon S, Longmuss E, Rolff J, Jager S, Eggert A, Delebinski C, Seifert G (2018) GADD45A and CDKN1A are involved in apoptosis and cell cycle modulatory effects of viscumTT with further inactivation of the STAT3 pathway. Sci Rep 8:1-14. https://doi.org/10.1038/s41598-018-24075-x

Klingbeil MG, Xavier FCA, Sardinha LR, Severino P, Mathor MB, Rodrigues RV, Pinto DS (2013) Cytotoxic effects of mistletoe (Viscum album L.) in head and neck squamous cell carcinoma cell lines. Oncol Rep 30:2316-2322. https://doi.org/10.3892/ or. 2013.2732

Ko BS, Kang S, Moon BR, Ryuk JA, Park S (2016) A 70\% ethanol extract of mistletoe rich in betulin, betulinic acid, and oleanolic acid potentiated $\beta$-cell function and mass and enhanced hepatic insulin sensitivity. Evid Based Complement Altern Med 7836823:13. https://doi.org/10.1155/2016/7836823

Kovacs E (2000) Serum levels of IL-12 and the production of IFNgamma, IL-2 and IL-4 by peripheral blood mononuclear cells (PBMC) in cancer patients treated with Viscum album extract. Biomed Pharmacother 54:305-310. https://doi.org/10.1016/ S0753-3322(00)80052-9

Kumar P, Kumar D, Kaushik D, Kumar S (2016) Screening of neuropharmacological activities of Viscum album and estimation of major flavonoid constituents using TLC densitometry. Int J Toxicol Pharmacol Res 8:179-186

Kunz C, Heiligtag HR, Hintze A, Urech K (2011) Treatment of basal cell carcinoma with Viscum album lipophilic extract-a case series study. Phytomedicine 18:S25. https://doi.org/10.1016/j. phymed.2011.09.060
Kuonen R, Weissenstein U, Urech K, Kunz M, Hostanska K, Estko M, Heusser P, Baumgartner S (2013) Effects of lipophilic extract of Viscum album L. and oleanolic acid on migratory activity of NIH/3T3 fibroblasts and on HaCat keratinocytes. Evid Based Complement Alternat Med 2013:718105. https:// doi.org/10.1155/2013/718105

Kusi M, Shrestha K, Malla R (2015) Study on phytochemical, antibacterial, antioxidant and toxicity profile of Viscum album Linn associated with Acacia catechu. Nepal J Biotechnol 3:60-65. https://doi.org/10.3126/njb.v3i1.14234

Ladokun O, Ojezele M, Arojojoye O (2015) Comparative study on the effects of aqueous extracts of Viscum album (mistletoe) from three host plants on hematological parameters in albino rats. Afr Health Sci 15:606-612. https://doi.org/10.4314/ahs. v15i2.38

Lee SH, Kim IB, Kim JB, Park DH, Min KJ (2014) The effects of Korean mistletoe extract on endurance during exercise in mice. Anim Cells Syst (Seoul) 18:34-40. https://doi.org/10.1080/19768 354.2014.881917

Lev E, Ephraim M, Ben-Arye E (2011) European and Oriental mistletoe: from mythology to contemporary integrative cancer care. Eur J Integr Med 3:e133-e137. https://doi.org/10.1016/J.EUJIM .2011 .05 .052

Li Y, Zhao YL, Huang N, Zheng YT, Yang YP, Li XL (2008) Two new phenolic glycosides from Viscum articulatum. Molecules 13:2500-2508. https://doi.org/10.3390/molecules 13102500

Lim NJ, Shin JH, Kim HJ, Lim Y, Kim JY, Lee WJ, Han SJ, Kwon O (2017) A combination of Korean mistletoe extract and resistance exercise retarded the decline in muscle mass and strength in the elderly: a randomized controlled trial. Exp Gerontol 87:48-56. https://doi.org/10.1016/j.exger.2016.11.003

Lyu SY, Choi SH, Park WB (2002) Korean mistletoe lectin-induced apoptosis in hepatocarcinoma cells is associated with inhibition of telomerase via mitochondrial controlled pathway independent of p53. Arch Pharm Res 25:93-101. https://doi.org/10.1007/ BF02975269

Melo MNO, Oliveira AP, Wiecikowski AF, Carvalho RS, Castro JL, de Oliveira FAG, Pereira HMG, da Veiga VF, Capello MMA, Rocha L, Holandino C (2018) Phenolic compounds from Viscum album tinctures enhanced antitumor activity in melanoma murine cancer cells. Saudi Pharm J 26:311-322. https://doi.org/10.1016/j. jsps.2018.01.011

Menke K, Schwermer M, Falke K, Eisenbraun J, Schramm A, Zuzak TJ (2019) Preclinical investigation of interaction of mistletoe extract (Viscum album L.) with radio- and chemotherapy in pediatric tumor cell lines. Phytomedicine 61:4. https://doi. org/10.1016/j.phymed.2019.09.123

Mishra R, Sharma S, Sharma RS, Singh S, Sardesai MM, Sharma S, Mishra V (2018) Viscum articulatum Burm. f. aqueous extract exerts antiproliferative effect and induces cell cycle arrest and apoptosis in leukemia cells. J Ethnopharmacol 219:91-102. https://doi.org/10.1016/J.JEP.2018.03.005

Mojiminiyi FBO, Owolabi ME, Igbokwe UV, Ajagbonna OP (2008) The vasorelaxant effect of Viscum album leaf extract is mediated by calcium-dependent mechanism. Niger J Physiol Sci 23:115-120. https://doi.org/10.4314/njps.v23i1-2.54947

Montero GD, Valladares MB, Tornes CYLF, Agramonte REA, Calderon JB, Fundora HR (2016) Tratamiento homeopático y convencional de la hipertensión arterial. Rev Méd Homeopat 9:53-58. https://doi.org/10.1016/J.HOMEO.2016.07.005

Nacsa-Farkas E, Kerekes E, Kerekes EB, Krisch J, Roxana P, Vlad DC, Ivan P, Vagvolgyi C (2014) Antifungal effect of selected European herbs against Candida albicans and emerging pathogenic non-albicans Candida species. Acta Biol Szeged 58:61-64 
Naganjaneyulu R, Kumar CKA, Kumar GA, Dalith MD, Basha DJ (2011) Antiulcer activity of Viscum articulatum Burm f. (viscaceae). Int J Innov Pharm Res 2:139-143

Ng TKS, Ho CSH, Tam WWS, Kua EH, Ho RC (2019) Decreased serum brain-derived neurotrophic factor (BDNF) levels in patients with Alzheimer's disease (AD): a systematic review and meta-analysis. Int J Mol Sci 20:1-26. https://doi.org/10.3390/ ijms 20020257

Nimse SB, Pal D (2015) Free radicals, natural antioxidants, and their reaction mechanisms. RSC Adv 5:27986-28006. https://doi. org/10.1039/c4ra13315c

Nna VU, Ofem OE, Oka VO, Aluko EO, Ofutet EO (2014) Comparative effects of Aloe vera gel and aqueous leaf extract of Viscum album on bilirubin excretion in streptozotocin-induced diabetic rats. Int J Biochem Res Rev 4:99-115. https://doi.org/10.9734/ ijbcrr/2014/7512

Nna VU, Oka VO, Aluko EO, Helen OT (2013) Comparative effects of aqueous leaf extract of Viscum album (Mistletoe ) and Aloe vera gel in the management of streptozotocin-induced diabetes mellitus. Int J Diabetes Res 2:84-89. https://doi.org/10.5923/j. diabetes.20130205.01

Nwaegerue E, Nweke IN, Ezeala CC, Unekwe PC (2007) Glucose lowering effect of leaf extracts of Viscum album in normal and diabetic rats. J Res Med Sci 12:235-240

Obi RK, Shenge JA (2018) In vitro antiviral activities of Bryophyllum pinnatum (Odaa opuo) and Viscum album (Awuruse). Res J Microbiol 13:138-146. https://doi.org/10.3923/jm.2018.138.146

Oei SL, Thronicke A, Schad F (2019) Mistletoe and immunomodulation: insights and implications for anticancer therapies. Evid Based Complement Altern Med 2019:1-6. https://doi. org/10.1155/2019/5893017

Ofem OE, Eno AE, Imoru J, Nkanu E, Unoh F, Ibu JO (2007) Effect of crude aqueous leaf extract of Viscum album (mistletoe) in hypertensive rats. Indian J Pharmacol 39:15-19. https://doi. org/10.4103/0253-7613.30756

Ofem OE, Eno AE, Nku CO, Antai AB (2009) Viscum album (mistletoe) extract prevents changes in levels of red blood cells, PCV, $\mathrm{Hb}$, serum proteins and ESR in high salt-fed rats. J Ethnopharmacol 126:421-426. https://doi.org/10.1016/j.jep.2009.09.021

Ofem OE, Nna VU, Essien NM (2014) Reduction in serum bilirubin concentration following administration of crude leaf extract of Viscum album (mistletoe) in high salt fed rats. Br J Pharm Res 4:352-361. https://doi.org/10.9734/BJPR/2014/7359

Ogbonnanya AE, Mounmbegna EP, Monago CC (2010) Effect of ethanolic extract of mistletoe (Viscum album L.) leaves on paracetamol-induced hepatotoxicity in rats. J Pharm Res 3:1888-1891

Oguntoye SO, Olatunji GA, Kolawole OM, Enonbun KI (2008) Phytochemical screening and antibacterial activity of Viscum album (mistletoe) extracts. Plant Sci Res 1:44-46

Ohiri FC, Esimone CO, Nwafor SV, Okoli CO, Ndu OO (2003) Hypoglycemic properties of Viscum album (mistletoe) in alloxaninduced diabetic animals. Pharm Biol 41:184-187. https://doi. org/10.1076/phbi.41.3.184.15098

Önal S, Timur S, Okutucu B, Zihnioğlu F (2005) Inhibition of $\alpha$-glucosidase by aqueous extracts of some potent antidiabetic medicinal herbs. Prep Biochem Biotechnol 35:29-36. https://doi. org/10.1081/PB-200041438

Önay-Uçar E, Karagöz A, Arda N (2006) Antioxidant activity of Viscum album ssp. album. Fitoterapia 77:556-560. https://doi. org/10.1016/j.fitote.2006.08.001

Orhan DD, Aslan M, Sendogdu N, Ergun F, Yesilada E (2005) Evaluation of the hypoglycemic effect and antioxidant activity of three Viscum album subspecies (European mistletoe) in streptozotocin-diabetic rats. J Ethnopharmacol 98:95-102. https://doi. org/10.1016/J.JEP.2004.12.033
Orhan DD, Küpeli E, Yesilada E, Ergun F (2006) Anti-inflammatory and antinociceptive activity of flavonoids isolated from Viscum album ssp. album. Z Naturforsch 61c:26-30. https://doi. org/10.1515/znc-2006-1-205

Orhan DD, Senol FS, Hosbas S, Orhan IE (2014) Assessment of cholinesterase and tyrosinase inhibitory and antioxidant properties of Viscum album L. samples collected from different host plants and its two principal substances. Ind Crops Prod 62:341-349. https://doi.org/10.1016/J.INDCROP.2014.08.044

Papuc C, Crivineanu M, Goran G, Nicorescu V, Durdun N (2010) Free radicals scavenging and antioxidant activity of European mistletoe (Viscum album) and European Birthwort (Aristolochia clematitis). Rev Chim 61:619-622

Park JH, Kim YN, Kim JK, Park HY, Song BS (2019) Viscothionin purified from mistletoe (Viscum album var. coloratum Ohwi) induces insulin secretion from pancreatic beta cells. J Ethnopharmacol 234:172-179. https://doi.org/10.1016/j.jep.2019.01.014

Park R, Kim MS, So HS, Jung BH, Moon SR, Chung SY, Ko CB, Kim BR, Chung HT (2000) Activation of c-Jun N-terminal kinase 1 (JNK1) in mistletoe lectin II-induced apoptosis of human myeloleukemic U937 cells. Biochem Pharmacol 60:1685-1691. https ://doi.org/10.1016/S0006-2952(00)00482-2

Park WB, Lyu SY, Kim JH, Choi SH, Chung HK, Ahn SH, Hong SY, Yoon TJ, Choi MJ (2001) Inhibition of tumor growth and metastasis by Korean mistletoe lectin is associated with apoptosis and antiangiogenesis. Cancer Biother Radiopharm 16:439-447. https ://doi.org/10.1089/108497801753354348

Park YK, Do YR, Jang BC (2012) Apoptosis of K562 leukemia cells by Abnobaviscum $\mathrm{F}^{\circledR}$, a European mistletoe extract. Oncol Rep 28:2227-2232. https://doi.org/10.3892/or.2012.2026

Patil CR, Jadhav RB, Singh PK, Mundada S, Patil PR (2010) Protective effect of oleanolic acid on gentamicin induced nephrotoxicity in rats. Phyther Res 24:33-37. https://doi.org/10.1002/ptr.2861

Pietrzak W, Nowak R, Gawlik-Dziki U, Lemieszek MK, Rzeski W (2017) LC-ESI-MS/MS identification of biologically active phenolic compounds in mistletoe berry extracts from different host trees. Molecules 22:1-15. https://doi.org/10.3390/molecules2 2040624

Poruthukaren KJ, Palatty PL, Baliga MS, Suresh S (2014) Clinical evaluation of Viscum album mother tincture as an antihypertensive: a plot study. J Evid Based Complement Altern Med 19:3135. https://doi.org/10.1177/2156587213507726

Radenkovic M, Ivetic V, Popovic M, Brankovic S, Gvozdenovic L (2009) Effects of mistletoe (Viscum album L., Loranthaceae) extracts on arterial blood pressure in rats treated with atropine sulfate and hexocycline. Clin Exp Hypertens 31:11-19. https:// doi.org/10.1080/10641960802409820

Saha C, Hegde P, Friboulet A, Bayry J, Kaveri SV (2015) Viscum album-mediated COX-2 inhibition implicates destabilization of COX-2 mRNA. PLoS ONE 10:e0114965. https://doi. org/10.1371/journal.pone.0114965

Sakalli Çetin E, Tetiker H, İlhan Çelik Ö, Yilmaz N, Hakki Cigerci I (2017) Methotrexate-induced nephrotoxicity in rats: protective effect of mistletoe Viscum album L.) extract. Complement Med Res 24:364-370. https://doi.org/10.1159/000468984

Satish S, Raveesha KA, Janardhana GR (1999) Antibacterial activity of plant extracts on phytopathogenic Xanthomonas campestris pathovars. Lett Appl Microbiol 28:145-147. https://doi.org/10. 1046/j.1365-2672.1999.00479.x

Schaller G, Urech K, Giannattasio M (1996) Cytotoxicity of different viscotoxins and extracts from the European subspecies of Viscum album L. Phyther Res 10:473-477. https://doi.org/10.1002/ (SICI)1099-1573(199609)10:6<473:AID-PTR879>3.0.CO;2-Q

Schink M, Tröger W, Dabidian A, Goyert A, Scheuerecker H, Meyer J, Fischer IU, Glaser F (2007) Mistletoe extract reduces the surgical suppression of natural killer cell activity in cancer patients. A 
randomized phase III trial. Complement Med Res 14:9-17. https ://doi.org/10.1159/000098135

Schläppi M, Ewald C, Kuehn JJ, Weinert T, Huber R (2017) Fever therapy with intravenously applied mistletoe extracts for cancer patients: a retrospective study. Integr Cancer Ther 16:479-484. https://doi.org/10.1177/1534735416658121

Schötterl S, Miemietz JT, Ilina EI, Wirsik NM, Ehrlich I, Gall A, Huber SM, Lentzen H, Mittelbronn M, Naumann U (2019) Mistletoebased drugs work in synergy with radio-chemotherapy in the treatment of glioma in vitro and in vivo in glioblastoma bearing mice. Evid Based Complement Alternat Med 2019:1376140. https://doi.org/10.1155/2019/1376140

Semiglasov VF, Stepula VV, Dudov A, Lehmacher W, Mengs U (2004) The standardised mistletoe extract PS76A2 improves QoL in patients with breast cancer receiving adjuvant $\mathrm{CMF}$ chemotherapy: a randomised, placebo-controlled, double-blind, multicentre clinical trial. Anticancer Res 24:1293-1302

Sengul M, Yildiz H, Gungor N, Cetin B, Eser Z, Ercisli S (2009) Total phenolic content, antioxidant and antimicrobial activities of some medicinal plants. Pak J Pharm Sci 22:102-106

Shah SS, Rehman YU, Iqbal A, Rahman ZU, Zhou B, Peng M, Li Z (2017) Phytochemical screening and antimicrobial activities of stem, leaves and fruit extracts of Viscum album L. J Pure Appl Microbiol 11:1337-1349

Shahaboddin ME, Pouramir M, Moghadamnia AA, Lakzaei M, Mirhashemi SM, Motallebi M (2011) Antihyperglycemic and antioxidant activity of Viscum album extract. Afr J Pharm Pharmacol 5:432-436. https://doi.org/10.5897/AJPP11.136

Sharma V, Dutt S, Kumar R, Sharma P, Javed A, Guleria R (2015) OPIOID Pharmacology: a review. IJSRST 1:1-11

Siegle I, Fritz P, McClellan M, Gutzeit S, Mürdter TE (2001) Combined cytotoxic action of Viscum album agglutinin-1 and anticancer agents against human A549 lung cancer cells. Anticancer Res 21:2687-2691

Stammer RM, Kleinsimon S, Rolff J, Jager S, Eggert A, Seifert G, Delebinski CI (2017) Synergistic antitumour properties of viscumTT in alveolar rhabdomyosarcoma. J Immunol Res 2017:1-13. https ://doi.org/10.1155/2017/4874280

Steele ML, Axtner J, Happe A, Kröz M, Matthes H, Schad F (2015) Use and safety of intratumoral application of European mistletoe (Viscum album L.) preparations in oncology. Integr Cancer Ther 14:140-148. https://doi.org/10.1177/1534735414563977

Steinborn C, Klemd AM, Sanchez-Campillo AS, Rieger S, Scheffen M, Sauer B, Garcia-Kaufer M, Urech K, Follo M, Ucker A, Kienle GS, Huber R, Grundemann C (2017) Viscum album neutralizes tumor-induced immunosuppression in a human in vitro cell model. PLoS ONE 12:e0181553. https://doi. org/10.1371/journal.pone. 0181553

Stoss M, Gorter RW (1998) No evidence of IFN- $\gamma$ increase in the serum of HIV-positive and healthy subjects after subcutaneous injection of a non-fermented Viscum album L. extract. Nat Immun 16:157-164. https://doi.org/10.1159/000069440

Stoss M, Van Wely M, Musielsky H, Gorter RW (1999) Study on local inflammatory reactions and other parameters during subcutaneous mistletoe application in HIV-positive patients and HIV-negative subjects over a period of 18 weeks. Arzneimittelforschung 49:366-373. https://doi.org/10.1055/s-0031-13004 28

Suveren E, Baxter GF, Iskit AB, Turker AU (2017) Cardioprotective effects of Viscum album L. subsp. album (European misletoe) leaf extracts in myocardial ischemia and reperfusion. J Ethnopharmacol 209:203-209. https://doi.org/10.1016/J. JEP.2017.07.010

Szurpnicka A, Zjawiony JK, Szterk A (2019) Therapeutic potential of mistletoe in CNS-related neurological disorders and the chemical composition of Viscum species. J Ethnopharmacol 231:241-252. https://doi.org/10.1016/j.jep.2018.11.025

Tabiasco J, Pont F, Fournié J-J, Vercellone A (2002) Mistletoe viscotoxins increase natural killer cell-mediated cytotoxicity. Eur J Biochem 269:2591-2600. https://doi.org/10.104 6/j.1432-1033.2002.02932.x

Tenorio-Lopez FA, Del Valle ML, Olvera GZ, Narvaez JCT, Pastelin G (2006) Viscum album aqueous extract induces NOS-2 and NOS-3 overexpression in Guinea pig hearts. Nat Prod Res 20:1176-1182. https://doi.org/10.1080/14786410600898979

Tenorio FA, del Valle L, González A, Pastelín G (2005) Vasodilator activity of the aqueous extract of Viscum album. Fitoterapia 76:204-209. https://doi.org/10.1016/J.FITOTE.2004.12.013

Thies A, Nugel D, Pfüller U, Schumacher U (2005) Influence of mistletoe lectins and cytokines induced by them on cell proliferation of human melanoma cells in vitro. Toxicology 207:105-116. https ://doi.org/10.1016/j.tox.2004.09.009

Tsyvunin V, Shtrygol S, Prokopenko Y, Georgiyants V, Blyznyuk N (2016) Influence of dry herbal extracts on pentylenetetrazoleinduced seizures in mice: screening results and relationship "chemical composition-pharmacological effect". Sci Pharm Sci 1:18-28. https://doi.org/10.15587/2519-4852.2016.71518

Turker AU, Yildirim AB, Karakas FP (2012) Antitumor and antibacterial activities of Viscum album L. grown on different host trees. Spat DD 2:229-236. https://doi.org/10.5455/spatula.2012122405 2924

Turkkan A, Savas HB, Yavuz B, Yigit A, Uz E, Bayram NA, Kale B (2016) The prophylactic effect of Viscum album in streptozotocin-induced diabetic rats. North Clin Istanbul 3:83-89. https ://doi.org/10.14744/nci.2016.22932

Tusenius KJ, Spoek AM, van Hattum J (2005) Exploratory study on the effects of treatment with two mistletoe preparations on chronic hepatitis C. Arzneimittelforschung 55:749-753. https://doi. org/10.1055/s-0031-1296925

Tusenius KJ, Spoek JM, Kramers CW (2001) Iscador Qu for chronic hepatitis C: an exploratory study. Complement Ther Med 9:1216. https://doi.org/10.1054/ctim.2000.0408

Twardziok M, Kleinsimon S, Rolff J, Jager S, Eggert A, Seifert G, Delebinski CI (2016) Multiple active compounds from Viscum album L. synergistically converge to promote apoptosis in ewing sarcoma. PLoS ONE 11:e0159749. https://doi.org/10.1371/journ al.pone.0159749

Twardziok M, Meierhofer D, Börno S, Timmermann B, Jager S, Boral S, Eggert A, Delebinski CI, Seifert G (2017) Transcriptomic and proteomic insight into the effects of a defined European mistletoe extract in Ewing sarcoma cells reveals cellular stress responses. BMC Complement Altern Med 17:237. https://doi.org/10.1186/ s12906-017-1715-2

Umoh UF, Ekpo BAJ, Bala DN, Udobang JA, Cocobassey M, Etim EI (2011) Phytochemical and comparative antidiabetic studies of leaf extracts of Viscum album from different plant hosts. Int J Biol Chem Sci 5:1448-1454. https://doi.org/10.4314/ijbcs .v5i4.11

Vicas S, Prokisch J, Rugina D, Socaciu C (2009) Hydrophilic and lipophilic antioxidant activities of mistletoe (Viscum album) as determined by FRAP method. Not Bot Hortic Agrobot Cluj-Napoca 37:112-116. https://doi.org/10.15835/nbha3723244

Vicas SI, Rugina D, Leopold L, Pintea A, Socaciu C (2011) HPLC fingerprint of bioactive compounds and antioxidant activities of Viscum album from different host trees. Not Bot Hortic Agrobot Cluj-Napoca 39:48-57. https://doi.org/10.15835/nbha3913455

von Schoen-Angerer T, Madeleyn R, Kienle G, Kiene H, Vagedes J (2015) Viscum album in the treatment of a girl with refractory childhood absence epilepsy. J Child Neurol 30:1048-1052. https ://doi.org/10.1177/0883073814541473 
Yang P, Jiang Y, Pan Y, Ding X, Rhea P, Ding J, Hawke DH, Felsher D, Narla G, Lu Z, Lee RT (2019) Mistletoe extract Fraxini inhibits the proliferation of liver cancer by down-regulating c-Myc expression. Sci Rep 9:6428. https://doi.org/10.1038/s41598-01941444-2

Yoon TJ, Yoo YC, Kang TB, Her E, Kim SH, Kim K, Azuma I, Kim JB (2001) Cellular and humoral adjuvant activity of lectins isolated from Korean mistletoe (Viscum album colaratum). Int Immunopharmacol 1:881-889. https://doi.org/10.1016/s1567 $-5769(01) 00024-8$

Yusuf L, Oladunmoye MK, Ogundare AO (2015) Hepatoprotective effect of methanolic leave extracts of $V$. album on paracetamolinduced laboratory animals. Int J Pharmacol Phytochem Ethnomedicine 1:46-54. https://doi.org/10.18052/www.scipress.com/ ijppe.1.46
Yusuf L, Oladunmoye MK, Ogundare AO (2013) In-vivo antibacterial activities of mistletoe (Viscum album) leaves extract growing on cocoa tree in Akure North, Nigeria. Eur J Biotechnol Biosci $1: 37-42$

Yusuf L, Oladunmoye MK, Ogundare AO, Mohmo AO, Daudu OAY (2014) Comparative antifungal and toxicological effects of the extract of mistletoes growing on two different host plants in Akure North, Nigeria. Int J Biotechnol Food Sci 2:31-34

Publisher's Note Springer Nature remains neutral with regard to jurisdictional claims in published maps and institutional affiliations. 